\title{
GSUE: Urban geochemical mapping in Great Britain
}

F. M. Fordyce ${ }^{1}$, S. E. Brown ${ }^{2}$, E. L. Ander ${ }^{2}$, B.G. Rawlins ${ }^{2}$, K. E. O’Donnell ${ }^{2}$, T. R. Lister $^{2}$, N. Breward ${ }^{2}$ and C. C. Johnson ${ }^{2}$

1 British Geological Survey, West Mains Road, Edinburgh, EH9 3LA, UK (fmf@bgs.ac.uk) Corresponding author

2 British Geological Survey, Keyworth, Nottingham, NG12 5GG, UK

\section{ABSTRACT:}

The British Geological Survey is responsible for the national strategic geochemical survey of Great Britain. As part of this programme, the Geochemical Surveys of Urban Environments (GSUE) project was initiated in 1992 and to date, 21 cities have been mapped. Urban sampling is based upon the collection of top (0.05 to $0.20 \mathrm{~m}$ ) and deeper ( 0.35 to $0.50 \mathrm{~m}$ ) soil samples on a $500 \mathrm{~m}$ grid across the built environment (1 sample per $0.25 \mathrm{~km}^{2}$ ). Samples are analysed for $c .46$ total element concentrations by X-ray Fluorescence Spectrometry (XRFS), $\mathrm{pH}$ and loss on ignition (LOI) as an indicator of organic matter content. The data provide an overview of the urban geochemical signature and because they are collected as part of a national baseline programme, can be readily compared with soils in the rural hinterland to assess the extent of urban contamination. The data are of direct relevance to current UK land use planning, urban regeneration and contaminated land legislative regimes. An overview of the project and applications of the data to human health risk assessment, water quality protection and contaminant source identification are presented.

\section{KEYWORDS:}

Urban geochemical mapping; soil; contaminants; land quality; potentially harmful elements 


\section{INTRODUCTION}

The British Geological Survey (BGS) is responsible for carrying out the national strategic geochemical survey of Great Britain and Northern Ireland, the Geochemical Baseline Survey of the Environment (G-BASE) programme. The programme began in the late 1960s in the north of the country and, working southwards, is due to complete coverage by 2020. The programme is based primarily on the collection of stream sediment samples at a density of 1 per $1.5 \mathrm{~km}^{2}$, however, rural soil samples (at a sample density of 1 per $2 \mathrm{~km}^{2}$ ) and a greater range of determinands in stream waters have been incorporated into the programme in more recent years (see Johnson et al. this volume). Historically, the programme avoided sampling in urban areas so that the rural geochemical baseline could be established.

However, at the start of the 1990s, United Kingdom (UK) government targets to build $60 \%$ of new homes (4.4 million) on brownfield sites by 2016 and city regeneration programmes lead to an increased interest in the quality of urban land (DETR 1998). In response to growing concerns about potentially harmful elements (PHE) in the urban environment and new statutory requirements for UK local authorities to manage contaminated land (Environmental Protection Act Part IIa 1990), urban geochemical mapping commenced in 1992.

The Geochemical Surveys of Urban Environments (GSUE) project, developed from preliminary studies carried out in collaboration with Imperial College, London in Wolverhampton and Richmond-on-Thames (Kelly et al. 1996; Bridge et al. 1997; Kelly 1997) and to date, 21 urban centres have been sampled (McMillan et al. 2001 and Fig. 1).

The concentrations of many PHE are enhanced in the urban environment as a result of atmospheric and terrestrial contamination and the nature of urban ground, 
which is often disturbed and in-filled and bears little relation to the soils, bedrock and superficial cover of the surrounding rural hinterland (Thornton et al. 1985; Wong 1996; Birke \& Rauch 2000; Mielke et al. 2000; Sanchez-Martin et al. 2000; Tijhuis et al. 2002; Imperato et al. 2003; Peltola \& Astrom 2003). Even in completely undisturbed urban areas such as parks, many PHE signatures are elevated relative to the rural background due to atmospheric contamination, littering, urban surface runoff and other factors (Chronopoulos et al. 1997; Ander et al. 2001). Hence it is necessary to establish the overall urban signature so that areas of concern within a city can be highlighted and detailed site investigation and contamination studies can be assessed in terms of the urban geochemical profile in addition to the rural background. It should be noted that systematic urban surveys do not replace the need for sitespecific contaminated land investigations; rather the data provide the citywide framework and context to more detailed assessments.

\section{METHODS}

Urban surveying is based upon the collection of soil samples on a systematic grid. Soils are sampled at a density of 4 per $\mathrm{km}^{2}$ across the built-up area whereby each UK National Grid kilometre square as defined from 1: 25000 scale topographic maps (Ordnance Survey ${ }^{\circledR}$ ) is split into four 500 m x 500 m sub-cells. Samples are collected from open ground as close as possible to the centre of each $500 \mathrm{~m}$ cell. Typical locations for sampling include gardens, parks, sports fields, road verges, allotments, open spaces, schoolyards and waste ground. Whilst attempts are made to select the least disturbed area of open ground as close as possible to the centre of the $500 \mathrm{~m}$ cell, contamination is not purposefully avoided as the aim of the survey is to provide an overview of the urban geochemistry and not to establish a 'near natural' geochemical 
baseline. Although the aim is a systematic survey, the regularity of the sampling grid is often constrained by the amount of surface sealing and accessibility of soils in the city environment (see Johnson et al. this volume).

A standard depth rather than horizon-based sampling strategy is adopted to be consistent with rural G-BASE soils (see Johnson et al. this volume) and because soil profiles in the urban environment are often poorly developed and disturbed. Surface (0.05 to $0.20 \mathrm{~m})$ and profile $(0.35$ to $0.50 \mathrm{~m})$ samples are collected using a handheld Dutch auger. Each sample is a composite of five sub-samples collected from the corners and centre of a 20 x 20 m square in accordance with standard G-BASE (Johnson et al. 2003) and international (Salminen et al. 1998) methods (Fig. 2). This sampling strategy provides information on the chemistry of near-surface soils, which may be influenced by atmospheric contamination, and of deeper soils, which should more closely represent substrate materials at each site. The sub-samples are homogenised at site to form one surface sample and one deeper sample from each location.

Observations of soil colour, depth and clast lithology and abundance are recorded at site, and the samples are classified into five textural groups (sand, sandsilt, silt, silt-clay and clay). Information on the location, geology, contamination, land use and other features required for data interpretation are also entered on a computercompatible data-card in a standard G-BASE/GSUE format (see Johnson et al. this volume).

Following collection, the soils are air- and then freeze-dried at $<30{ }^{\circ} \mathrm{C}$ to prevent the volatilsation of Se and Hg. During the 1990s the surface soil samples were sieved to $<2 \mathrm{~mm}$, the environmental standard whereas deeper soil samples were sieved to $<150 \mu \mathrm{m}$ to be compatible with the rural stream sediment and soil data 
collected under the G-BASE programme. However, since 2000 both surface and deeper soil samples have been sieved to $<2 \mathrm{~mm}$ to allow better down-profile comparisons. The samples are then homogenised, coned and quartered and a $30 \mathrm{~g}$ subsample ground in an agate planetary ball mill until $95 \%$ is $<53 \mu \mathrm{m}$. The pulverised material is further sub-sampled to obtain portions for analysis. The number of determinands has increased from 18 in the early 1990s to the current suite of 46 total element concentrations by X-ray Fluorescence Spectrometry (XRFS) (Ingham \& Vrebos 1994; Johnson et al. this volume). These include elements of concern in terms of contaminated land such as $\mathrm{As}, \mathrm{Cd}, \mathrm{Cr}, \mathrm{Ni}$, and $\mathrm{Pb}$ (Table 1). However, the major element composition (for example, $\mathrm{CaO}, \mathrm{K}_{2} \mathrm{O}, \mathrm{Fe}_{2} \mathrm{O}_{3}$ and $\mathrm{MnO}$ ), soil $\mathrm{pH}$ and loss on ignition (LOI), as an indicator of organic matter content, are also analysed as these factors can influence the mobility of PHE in soils. Soil pH is determined by adding $10 \mathrm{~g}$ of $<2 \mathrm{~mm}$ sample to $25 \mathrm{ml}$ of $0.01 \mathrm{M} \mathrm{CaCl}{ }_{2} \cdot 2 \mathrm{H}_{2} \mathrm{O}$ (calcium chloride). The mixture is shaken to form a slurry prior to analysis by $\mathrm{pH}$ electrode. This method of $\mathrm{pH}$ determination generally gives lower results $(0.5 \mathrm{pH}$ units $)$ than water based methods (Rowell 1994). LOI is determined on $2 \mathrm{~g}$ of $<2 \mathrm{~mm}$ material heated in a furnace and kept at $450{ }^{\circ} \mathrm{C}$ for a minimum of 4 hours.

Once preparation is completed, sample residue materials are stored in the GSUE sample archive where they form part of the BGS National Geoscience Data Centre collection (Johnson et al. this volume).

The analytical results undergo the rigorous quality assurance procedures followed by the G-BASE programme (Johnson et al. this volume). Systematic error in field sampling and analysis is monitored using a method based on randomised sample site numbers (Plant 1973). Field-based procedures at each stage of the sampling process are designed to minimise error (Johnson et al. 2003). Six percent of the 
samples analysed are controls comprising field duplicate, analytical replicate and primary and secondary reference materials. Long-term analytical drift between batches of samples is monitored using time versus concentration plots for each of the reference samples. Tolerance limits are arbitrarily set at mean $\pm 2 \sigma$ to assess data quality. Simple arithmetic correlations are applied to normalise the data for systematic drift. Values below the lower limit of detection are assigned to a value of one half of the detection limit and all field duplicate sample results removed prior to statistical treatment (for example BGS 2000).

Sampling and analytical precision are calculated using a procedure based on analysis of variance (ANOVA). Plots of cumulative frequency versus concentration for each element in the soils are examined to assess the degree to which the elements conform to a Gaussian distribution; in most cases elements are log-transformed before undergoing ANOVA, to improve their conformity to the model distribution (Plant et al. 1975).

A random nested model of ANOVA is used because all the analyses are part of a single randomised dataset (Snedecor \& Cochran 1989). The NESTED procedure from the SAS ${ }^{\mathrm{TM}}$ statistical software package is used to perform the ANOVA (SAS Institute Inc. 1989). Residual variance (representing inter-alia inhomogeneities introduced in sample preparation and sub-sampling, and errors in chemical analysis), between-sample variance (representing within-site variability as well as any variability introduced by the process of sample collection) and between-site variance (representing the distribution of the elements in the soils) are calculated.

However, it should be noted that because the frequency distribution of most elements is multi-modal and none fit the Gaussian model perfectly, there is an unquantifiable overstatement of the between-site variance a problem that is inherent 
in using ANOVA on geochemical data. Statistical F-tests are not quoted because the data do not satisfy this and other assumptions required for formal ANOVA. Rather the data are described in terms of percentiles of the data distribution and 'average' values are based on the median concentration.

The percentage of variance attributable to between-site, between-sample and residual variance of duplicate and replicate surface soil pairs from 11 urban centres (Cardiff, Swansea, Stoke-on-Trent, Telford, York, Kingston-upon-Hull (Hull), Doncaster, Mansfield, Scunthorpe, Lincoln and Sheffield) are given in Table 2, and provide a general indication of the reliability of the geochemical data. In most cases over $90 \%$ of the variability can be attributed to between-site variance demonstrating the robustness of the field sampling method. ANOVA results for $\mathrm{Cu}, \mathrm{Cd}$, $\mathrm{Sn}$ and $\mathrm{U}$ fall below the $90 \%$ between-site-variance level largely as a result of the inhomogeneous nature of urban soils. Sample preparation and analytical variability (residual variance) is very low ( $<1.6 \%$ for most elements) indicating the reliability of the analytical techniques. Results for $\mathrm{Cd}, \mathrm{Sb}, \mathrm{Sn}$ and $\mathrm{U}$ probably reflect the fact that concentrations of these elements in soils are close to the limit of detection (Lister 2002).

Once error controlled and spatially registered, the urban geochemical data are stored digitally in the corporate BGS Geochemistry Database and are available to users under licence (Johnson et al. this volume; Coats \& Harris 1995).

\section{DATA PRESENTATION}

Geochemical data can be presented in a number of formats; the standard method for rural G-BASE data is as interpolated maps in the BGS series of geochemical atlases (for example, BGS 1997; BGS 2000). These maps comprise computer-generated 
surface grids for each element produced by interpolation of the real data using Inverse Distance Weighting (IDW) (Johnson et al. this volume). An example of a gridded urban soil geochemical map is given in Figure 3 and shows the concentrations of $\mathrm{Pb}$ in deeper $(0.50 \mathrm{~m})$ soils derived from a survey of 285 urban sites in the city of Wolverhampton in the English West Midlands undertaken in 1992-1993. The surrounding rural data are derived from the G-BASE regional survey completed as part of the Welsh and West-Central England geochemical atlas area (BGS 2000). Whilst the interpolated maps are a robust presentation method for rural geochemical data where element distributions tend to form regional patterns, urban soils are highly heterogeneous and variable over small distances and there is concern that urban data presented in this way could be misinterpreted if not accompanied by validation information to give an estimate of the likely level of error in the interpolation. ANOVA investigations of field duplicate data indicate that the urban sampling methodology is valid, namely samples collected from the same site are more similar than samples from different sites (Lister 2002). However, further studies into the spatial variability of urban data using nested sampling, variogram and cross-validation techniques (Fordyce \& Ander 2003; Rawlins \& Brown 2003) and geostatistical assessments of various gridding algorithms (Nathanial et al. 1997) demonstrate a large nugget effect of a range of PHE, namely that differences between concentrations over very short distances are similar to those at increasing distance. Hence commonly used interpolation techniques are likely to be of limited use. Indeed due to dilation effects caused by the programme algorithms, interpolated maps do not provide a suitable method for presenting urban data. At the close scale of interrogation necessary in urban areas, interpolations can give misleading results, as the spatial extent of high element values can be over-emphasised. 
As a result, methods of presenting urban geochemical data as graduated symbol maps using ArcView $® / \operatorname{ArcGIS}{ }^{\circledR}$ geographic information system (GIS) software packages have been adopted (Fig. 4). Figure 4 shows the concentrations of As in surface soils collected from 747 sites over an area of $195 \mathrm{~km}^{2}$ from the urban area of Stoke-on-Trent in the English Midlands during 1993. Although the geochemical patterns are not as readily identified as they are on interpolated maps, presentation of the data as graduated symbol maps avoids uncertain extrapolation between sampling points. Interpolated maps are still used with caution by the GSUE project to assess rural-urban soil comparisons and multi-element associations.

Once, plotted the GSUE data are presented as a series of BGS urban geochemistry reports (for example, Morley \& Ferguson 2001; Brown 2003; Fordyce \& Ander 2003; Rawlins \& Brown 2003; Freestone et al. 2004; O’Donnell 2004).

\section{DATA APPLICATIONS}

Urban geochemical data have a number of applications to current UK land quality legislation and urban planning needs as follows:

\section{Legislative drivers}

The distribution of chemical elements in the environment is of concern because although many are essential to life, at least 26 of the naturally occurring elements are potentially harmful to plants and animals in high doses (Mertz 1986; Fergusson 1990; WHO 1996; Fordyce \& Ander 2003). Many UK city environments have a long history of urbanisation resulting in elevated concentrations of PHE such as As, Cd, $\mathrm{Cr}, \mathrm{Cu}, \mathrm{Ni}, \mathrm{Pb}, \mathrm{V}$ and $\mathrm{Zn}$ derived from industrial and mineral processing and the atmospheric deposition of $\mathrm{Pb}$ and other toxins from traffic fumes and power 
generation (Thornton et al. 1985; Moir \& Thornton 1989; Farago et al. 1996; Paterson et al. 1996; Wang et al. 1997; Farmer et al. 1999). Whether or not these substances constitute a hazard depends on a variety of factors. These include their chemical form, concentration, mobility and behaviour in the environment, the extent to which they are taken up by living organisms (bioavailability), the properties of the substrate in which they occur such as the acidity of waters or soils, the soil texture and mineral composition, the level of exposure and the dose received (Farmer et al. 1989; Thornton et al. 1994; Mielke et al. 1997; Rieuwerts et al. 1998; DEFRA-EA 2002a; DEFRA-EA 2002b; Hough et al. 2004).

In UK urban areas, the major pathways via which PHE can enter the human body are through the inhalation of dusts and gases; direct contact with and ingestion of contaminated soil in gardens, play areas and allotments etc. Soil ingestion can be inadvertent for example from vegetables grown in the urban environment or from hand to mouth contact, especially in children. Deliberate eating of soils is also common among children. Water is unlikely to pose a risk to human health due to the high standard of public water quality in UK and the minimal use of private wells in city areas; however, the protection of water resources is a major issue in the urban environment (DEFRA-EA 2002a; DEFRA-EA 2002b).

Prompted by concerns about land and water quality, national governments and international agencies are developing policies to limit the amount and impacts of PHE in the environment. Although links between long term human health effects and PHE are often difficult to prove, the majority of regulatory authorities adopt a precautionary principal approach to legislate against high environmental concentrations. In the UK, the Environmental Protection Act, Part IIa (1990) places the responsibility for the identification, assessment, remediation and monitoring of 
contaminated land with local authorities and is based on a 'suitable for use' approach. Land is categorised as contaminated only if the current or intended use of a site has the potential to cause 'significant harm' to four receptors namely humans, ecosystems, water resources and buildings and operates a 'polluter pays' principle in terms of remediation. However, it is important to point out that Part IIa only applies to a sub-set of land that is chemically contaminated. The identification of contaminated land relies on the concept of risk assessment, based on a pollutant linkage whereby the presence or source of contamination has the potential to impact on a receptor by means of a pathway (Fig. 5). This approach requires that land be assessed for redevelopment on a site-specific basis (DETR 2000).

Threats to water quality are not only addressed under the UK Environmental Protection Act but are directly linked to the European Union (EU) Water Framework Directive, which requires the protection of all surface and groundwater bodies (CEC 1998; EA 2002).

\section{Soil guideline values and human risk assessment}

In terms of human risk assessment, in 2002 the UK government launched the Contaminated Land Exposure Assessment (CLEA) model (DEFRA-EA 2002c). The model adopts an ecotoxicological approach and considers the exposure to contaminants from the direct and indirect ingestion and inhalation of soils (DEFRAEA 2002a). To date, generic soil guideline values (SGV) for As, Cd, Cr, Pb, Hg, Ni and Se have been defined (DEFRA-EA 2003b) (Table 3). The GSUE project provides information for all these elements with the exception of $\mathrm{Hg}$, which due to budgetary constraints is not analysed routinely. Summary statistics for these PHE in surface soils from 14 urban centres are presented for the first time in Table 3. It is anticipated that 
data for the remaining 7 urban centres surveyed will be available by 2005. Table 3 represents the most comprehensive dataset on contaminant concentrations in UK urban soils since the work of Thornton et al. (1985).

Although the standard way to plot geochemical maps is using a full range of percentiles to describe the data distribution (Fig. 4), the data can also be presented to show where the SGV are exceeded thus highlighting areas for further investigation and follow-up. Figure 6 shows locations in the Stoke-on-Trent urban area where As concentrations in surface soils are above the SGV of $20 \mathrm{mg} / \mathrm{kg}$ for residential use (DEFRA-EA 2002d). The large number of sites reflects the general dispersion of As in the environment around Stoke-on-Trent due to the presence and exploitation of coal-bearing strata in the area; the dispersal of coal waste products as fill materials across the urban environment and the long industrial history of the city. However, the large number of sites is also a consequence of the low SGV for this element relative to natural abundances (Fordyce \& Ander 2003). Indeed further examination of As concentrations in surface soils from 13 of the cities surveyed by the GSUE project demonstrates that more than $50 \%$ of the soils sampled in Swansea, Manchester, Scunthorpe, Sheffield and Hull are above the SGV of $20 \mathrm{mg} / \mathrm{kg}$, which again is not only a measure of the industrial heritage of these cities but of the relatively low guideline value for this element compared to its natural distribution (Fig. 7). Although the SGV is exceeded, it is essential to point out that this is not an indication of actual risk, rather that further assessments should be carried out (DEFRA-EA 2002d). The BGS is working with a number of authorities to follow up areas highlighted by the GSUE survey for more detailed investigation.

For example, a geochemical survey of 389 soils from $97 \mathrm{~km}^{2}$ carried out in 2000 in the urban area of Coventry in the English Midlands, highlighted allotments 
with soil Cd concentrations in excess of the $1 \mathrm{mg} / \mathrm{kg}$ at soil pH $6 \mathrm{SGV}$ for areas where plants are grown. The mean $\mathrm{pH}$ of soils in the allotments was 6.1. Since the CLEA model assumes that $99 \%$ of the exposure to Cd may be through the consumption of homegrown vegetables (DEFRA-EA 2002e) there was potential concern of a sourcepathway-receptor linkage and risk to human health. Results of a follow-up soil and vegetation survey carried out in conjunction with the city authority demonstrate that the high $\mathrm{Cd}(>1 \mathrm{mg} / \mathrm{kg})$ and low $\mathrm{pH}(<6)$ values are not spatially extensive. The levels of Cd in vegetables are all below the European Union (EU) regulatory limit of $0.2 \mathrm{mg} / \mathrm{kg}$ fresh weight (FW) for leafy and $0.1 \mathrm{mg} / \mathrm{kg} \mathrm{FW}$ for stem and root vegetables (CEC 2001). The average daily exposure to Cd in soil estimated using the CLEA model indicates no significant toxicological risk for gardeners working at the allotments (Rawlins \& Brown 2003; Palumbo et al. 2004).

The GSUE data have also been used to develop risk assessment methods to determine $\mathrm{Cd}, \mathrm{Cu}, \mathrm{Ni}, \mathrm{Pb}$ and $\mathrm{Zn}$ exposure for populations living on and growing food in urban locations (Hough et al. 2004). The study showed that element concentrations in homegrown vegetables predicted from the GSUE soil data for Wolverhampton were satisfactory with the exception of $\mathrm{Pb}$. This is probably because plant $\mathrm{Pb}$ uptake via the root system is limited and the main source of $\mathrm{Pb}$ contamination in vegetables is via atmospheric deposition (Dalenberg \& Van Driel 1990). The study also demonstrated that the majority of the population were at low risk of health effects from vegetables grown on urban soils but highlighted particular areas associated with road junctions, railways and canals that may be inappropriate for residential use.

The UK SGV are based upon the assumption that $100 \%$ of the elements in soil are bioavailable (DEFRA-EA 2002b), and one of the further steps in a sourcepathway-receptor risk assessment is to investigate the likely bioavailability of 
potential contaminants in soil. In addition to studies of plant uptake, data from the GSUE project are being used to develop quantitative analytical methods to assess the human bioaccessibility of PHE in soils that are directly consumed. These are known as physiologically based extraction tests (PBET) and are designed to mimic conditions in the stomach during soil ingestion giving a more accurate assessment of exposure. The tests originated in the United States and to date have been validated against animal models for As and Pb (Ruby et al. 1996). The methods have been adapted for use in the UK and for example, when applied to surface soils from Cardiff, demonstrate that although total As concentrations of up to $150 \mathrm{mg} / \mathrm{kg}$ are recorded, the bioaccessibility ranges from only 6 to 15\% (Cave et al. 2003). The range in values highlights the site-specific nature of bioaccessibility, particularly in heterogeneous urban environments. This information is being used by the UK Environment Agency (EA) to direct its policy on the use of bioaccessibility data for ingested As in risk assessments.

\section{Threats to water quality}

The potential threats to groundwater from contaminants leaching down-profile from surface soils have been assessed using the GSUE data for Stoke-on-Trent (Fordyce \& Ander 2003). The method utilised the Blume \& Brummer (1991) and Boden (1994) groundwater vulnerability-leaching model, which requires the input of parameters that control the attenuation of specified contaminants in soils such as $\mathrm{pH}$, organic matter, clay and sesquioxide contents. Soil pH and organic matter (LOI \%) are measured as part of the GSUE survey and could be incorporated directly into the model. Clay and sesquioxide contents are not determined routinely but a simple system to derive this 
information from GSUE soil texture and colour data was developed (Fordyce \& Ander 2003).

The results demonstrate that due to the calcareous nature of the Coal Measures bedrock in Stoke-on-Trent and the base-rich character of the made ground underlying the city, soil $\mathrm{pH}$ values are circum-neutral over much of the area. As a result, the majority of soils have a high attenuation capacity and the leaching potential of the 11 contaminants examined (Cd, Mn, Ni, Co, $\mathrm{Zn}, \mathrm{Al}, \mathrm{Cu}, \mathrm{Cr} \mathrm{Pb}, \mathrm{Hg}$ and $\mathrm{Fe}$ ) is generally low. Although the model does not require soil PHE data, the benefit of the GSUE survey is that the element concentrations are known and can be evaluated in conjunction with the leaching potential results. Comparisons show that the regions of high element concentrations in the city centre correspond to soils with poor leaching potential therefore the risks of pollutant migration to groundwater are less. Potential leaching risks over the Triassic sandstones on the southeast of the urban periphery are of greater concern because of the poorer attenuation capacities of these soils and the importance of the Triassic sandstone aquifer for drinking water abstraction. However, comparisons with the GSUE data show that the majority of PHE in soils are found in low concentration over this lithology (Fig. 8).

Whilst it is possible to draw these very generalised conclusions about groundwater vulnerability using the GSUE data it should be noted that the hydrogeology of urban areas is normally extremely complex and further assessments of potential threats to groundwater quality are hampered due to the lack of net infiltration and depth to groundwater information. Although groundwater vulnerability maps produced by the EA in conjunction with the BGS and the National Soil Survey are available for England and Wales, urban areas are not characterised 
because of the unknown properties of urban fill materials (EA 1998; Palmer \& Lewis 1998).

\section{Rural - urban comparisons}

To provide an overview of the increased levels of PHE in urban environments relative to rural background, median values for urban areas can be compared to results for national datasets. National soil geochemical data generated by the Soil Survey of England and Wales National Inventory comprise surface soil total element concentrations ( $<2 \mathrm{~mm}$ fraction) based on collection at a sample density of 1 per 25 $\mathrm{km}^{2}$ (McGrath \& Loveland 1992) (Table 3). However, it should be noted that although the sampling depth $(0.15 \mathrm{~m})$ is similar to the GSUE surface soils, the analysis of the national samples is based on an extraction rather than a total technique (aqua-regia 4:1 $\mathrm{HCl}: \mathrm{HNO}_{3}$ vol/vol followed by inductively coupled plasma atomic emission spectrometry). This is likely to lead to some bias in the results when comparing one dataset to the other. None the less, comparisons of the median values demonstrate that in general $\mathrm{Cd}, \mathrm{Cr}$ and $\mathrm{Ni}$ concentrations are elevated up to 2.5 to 3 times and $\mathrm{Pb}$ up to 5 times national levels in most of the 14 cities presented in Table 3 giving an indication of the degree of contamination in the urban environment. Whilst these comparisons are interesting, they do not take account of natural variations in the rural baseline around individual cities.

The benefits of a systematic urban (GSUE) and regional (G-BASE) geochemical survey are that direct comparisons between urban and rural environments are possible. For example, Figure 3 shows the concentration of $\mathrm{Pb}$ in deeper $(0.50 \mathrm{~m})$ soils in the environment around Wolverhampton. Enhanced concentrations of the element in the urban environment are very evident relative to the 
rural hinterland. On a regional scale, Figure 9 shows information for $\mathrm{Cu}$ from seven of the urban centres in the Humber-Trent region of England in relation to the surrounding G-BASE rural soils data. Between 1994 and 1996, 6500 soil samples were collected by the G-BASE programme throughout this part of rural eastern England covering a total area of around $13000 \mathrm{~km}^{2}$. The rural-urban comparisons demonstrate that Hull and Sheffield, show greatest enhancement of $\mathrm{Cu}$ relative to rural baseline conditions.

Rural-urban relationships have been investigated in more detail in Stoke-onTrent. Table 4 outlines the data ranges for selected total element concentrations in GBASE rural and GSUE urban soils for the area. The rural soil samples were collected as part of the Northwest England and North Wales and Wales and West-Central England geochemical atlas areas (BGS 1997; BGS 2000). For the purposes of the rural-urban comparisons, a sub-set of the rural data was selected from an area underlain by the same lithological units as the city over a $10 \mathrm{~km}$ radius around Stokeon-Trent. On the basis of median values for deeper soils, the urban area contains $c$. 1.2 times the average $\mathrm{Cr}, \mathrm{Ni}, \mathrm{Sn}, \mathrm{Pb}$ and $\mathrm{Zn}$ of the rural hinterland, whereas As shows little elevation in the urban soils relative to rural background (Fordyce \& Ander 2003). Using GIS technology, it is now possible to readily select sub-sets of the geochemical data based on particular areas of interest. This is extremely useful to examine the relationships between rural and urban soils over particular stratigraphic units and parent materials in more detail (Fig. 10). Stoke is primarily underlain by Westphalian age sandstones, mudstones and coals and the Triassic age Sherwood Sandstone and Mercia Mudstone Groups (Wilson et al. 1992). Concentrations of V, $\mathrm{Fe}_{2} \mathrm{O}_{3}, \mathrm{Co}, \mathrm{Ni}, \mathrm{Cu}$ and $\mathrm{Zn}$ in soils are highest over the Westphalian rocks relative to other the stratigraphic units as expected due to the presence of coals (Fig. 10). 
However, these 'natural' geochemical variations are small compared to the contrast between rural and urban environments. Figure 10 shows that in almost all cases, element concentrations are enhanced in the urban relative to the rural environment for each stratigraphic unit. As a further comparison, the ratios of element median values in the urban versus rural deeper soils for each parent material type are shown in Table 5. Soils over river terrace deposits show some of the greatest increases in element concentrations between rural and urban environments (for example, $\mathrm{MnO}$ x2.7, $\mathrm{Zn}$ x2.9, $\mathrm{Pb}$ x2.4 and $\mathrm{Sn}$ x2.8). This may indicate that these deposits act as sinks for contaminants in cities and may also reflect the historical preference for locating industrial activity on the banks of drainage systems (Fordyce \& Ander 2003).

\section{Inter-city comparisons}

One of the benefits of a national systematic urban survey is that the results from different cities can be compared directly. For example, Figure 11 shows the median concentration of selected elements in Stoke-on-Trent, Cardiff, Telford and Swansea surface soils. These cities are all underlain by Westphalian Coal Measures and have a long history of industrialisation. Interestingly, the results are rather similar with the exception of Swansea where the import of ores and metal smelting contributes significantly to the soil contaminant load (Morley \& Ferguson 2001). Equally, Table 3 demonstrates that median concentrations of $\mathrm{Cr}$ are highest in Glasgow and Sheffield surface soils, two cities renowned throughout the world for their ore processing and steel making histories. In contrast, median concentrations of $\mathrm{As}, \mathrm{Cr}, \mathrm{Ni}$ and $\mathrm{Pb}$ in Lincoln and Mansfield are relatively low compared to other cities as these are small less industrialised urban centres (Table 3). Similarly, concentrations of $\mathrm{Cu}$ in Lincoln surface soils are similar to the rural baseline (Fig. 9). These comparisons are useful to 
establish 'typical' urban geochemical signatures and highlight exceptions that can be attributed to different current and historic land uses.

\section{Contaminant sources in the environment}

Rural-urban and inter-city comparisons are also important in the context of identifying possible contaminant sources in the environment.

Under the UK contaminated land regime, local authorities are required to identify and develop a strategy for managing contaminated land and the guidance to achieve this is based largely on current and historical land use. The likely types of contaminants associated with particular industrial activities are considered (DOE 1994; DOE 1995). However, the advantage of geochemical information is that the actual levels of contamination in the environment can be assessed independent of assumptions related to land use.

A broad-scale example is that in the highly industrialised city of Wolverhampton, highest soil $\mathrm{Pb}$ concentrations were associated with the industrial corridor to the east of the city centre as expected based on land use (Fig. 3). In contrast, sampling in the largely residential green suburban area of Richmond-onThames, London revealed high soil $\mathrm{Pb}$ concentrations proximal to the road network. However, concentrations of $\mathrm{Pb}$ in surface soils from Richmond-on-Thames were higher on average (median $185 \mathrm{mg} / \mathrm{kg}$ ) than Wolverhampton (median $101 \mathrm{mg} / \mathrm{kg}$ ), an outcome that would not be predicted from the historical land use records of the two urban areas alone (Kelly et al. 1996; Kelly 1997).

On-going work in the Humber-Trent region of Eastern England is a further example of the application of GSUE data to contaminant source identification in the context of rural and urban comparisons. During the summer of 1996, a soil 
geochemical survey was undertaken in the City of Hull, comprising 411 individual sampling locations across 160 square kilometres. Based on a subset of the surrounding G-BASE Humber-Trent rural survey data and the urban data from Hull, a preliminary surface soil geochemical map was generated for Sn over the region (Fig. 12). The map highlights a series of anomalously high Sn concentrations around the site of the former Capper Pass tin smelter, which was operational between 1937 and 1991. There is a clear trend of decreasing Sn concentrations at increasing distances from the smelter site, consistent with the dominant prevailing wind direction (from the southwest). Further work is currently being undertaken in conjunction with local agencies to assess the nature, magnitude and extent of aerial metal deposition related to the former operation of the smelter.

The relationships between element concentrations and different land types have been examined in more detail in Stoke-on-Trent (Fordyce \& Ander 2003). Stoke is an interesting urban environment as the presence of coal, ironstone and clay in the area resulted in rapid growth during the Industrial Revolution (c. 1760 onwards) and the city became a world-leading centre for coal, iron and steel and pottery manufacture. As a result of this long industrial heritage, the majority of Stoke-onTrent is built on urban fill and made ground material, much of which derived historically from industrial wastes. The types of made ground underlying the city had been mapped previously by the BGS (Wilson et al. 1992) allowing spatial comparisons with the soil geochemical information. Investigations were carried out using a combination of GIS spatial query function to select sub-sets of the geochemical data over different types of made ground and data within $250 \mathrm{~m}$ of the road and rail network followed by presentation as box and whisker plots (see for example Fig. 13); three-component maps of multi-element distributions (Breward et 
al. 1992); Spearman Rank correlation matrices and principle component analysis (Fordyce \& Ander 2003). The main element associations evident from these studies are outlined in Table 6.

Interestingly no overt geochemical signature with the road and rail network in Stoke-on-Trent was apparent. Due to falling levels of traffic-derived $\mathrm{Pb}$ in urban environments as a result of the widespread use of lead-free petrol in recent years, Monaci \& Bargagli (1997) and Monaci et al. (1999) have suggested that Ba is a good indicator of traffic fume contamination as it is added to diesel to reduce soot emissions (for example, Petkov et al. (1999). Elements such as Zn (used in tyres) are also enhanced in the urban environment as a result of road vehicle usage. However, none of these elements ( $\mathrm{Pb}, \mathrm{Ba}$ and $\mathrm{Zn}$ ) showed an association with the road network in Stoke-on-Trent. Undoubtedly traffic fumes do contribute to the metal loadings of soils in the city but the geochemical signature, as determined by the studies carried out to date, is not distinct because of the many other sources of these elements in this complex urban environment and naturally enhanced concentrations of elements such as Ba in the local bedrock (Fordyce \& Ander 2003).

In general, the main control on element distributions in soils from Stoke-onTrent is the presence of made ground. The majority of elements, with the exception of $\mathrm{SiO}_{2}$ and $\mathrm{MgO}$, are elevated over made ground compared to the rural periphery. Within the urban area, multi-element anomalies are associated with different industrial land uses and made ground types aiding the identification of possible contaminant sources. For example, As is enhanced in profile soils developed over domestic and industrial waste and ironworks slag (Fig. 13). In general, soils developed over coal spoil and coal ash waste are high in $\mathrm{Fe}_{2} \mathrm{O}_{3}, \mathrm{CaO}, \mathrm{MgO}, \mathrm{K}_{2} \mathrm{O}$, $\mathrm{Al}_{2} \mathrm{O}_{3}, \mathrm{SiO}_{2}, \mathrm{As}, \mathrm{Hg}, \mathrm{V}, \mathrm{Ni}, \mathrm{Cr}, \mathrm{Zn}, \mathrm{Cu}, \mathrm{Cd}, \mathrm{Ba}$ and $\mathrm{Pb}$ whereas domestic waste soils 
although containing high trace metal concentrations, have lower major element $\left(\mathrm{Al}_{2} \mathrm{O}_{3}, \mathrm{~K}_{2} \mathrm{O}, \mathrm{SiO}_{2} \mathrm{TiO}_{2}\right)$ contents. Soils developed over ironworks slag and former steel works sites have a distinctive geochemical signature, which is not only high in trace metals $\left(\mathrm{Fe}_{2} \mathrm{O}_{3}, \mathrm{Ni}, \mathrm{Cr}, \mathrm{Sn}, \mathrm{Mo}, \mathrm{Cd}, \mathrm{V}, \mathrm{Cu}\right.$ and $\left.\mathrm{Zn}\right)$, but in base metals such as $\mathrm{CaO}, \mathrm{MgO}$ and $\mathrm{P}_{2} \mathrm{O}_{5}$ reflecting the use of these products in the steel making process. The use of pigments containing $\mathrm{Cd}, \mathrm{Cr}, \mathrm{Cu}, \mathrm{Co}, \mathrm{Fe}, \mathrm{Mn}, \mathrm{Ni}, \mathrm{U}$ and $\mathrm{V}$ and ceramic glazes containing $\mathrm{SiO}_{2}, \mathrm{Al}_{2} \mathrm{O}_{3}, \mathrm{CaO}, \mathrm{SnO}_{2} \mathrm{PbO}$ and $\mathrm{FeTiO}_{2}$ in the potteries industry in Stoke-on-Trent account for localised anomalies due to historic factory emissions and dumping of ceramic waste.

Investigations into element associations also demonstrate that the concentrations of $\mathrm{Al}_{2} \mathrm{O}_{3}, \mathrm{SiO}_{2}, \mathrm{TiO}_{2}, \mathrm{MgO}$ and $\mathrm{Ba}$ in Stoke-on-Trent soils are largely controlled by geological processes whereas $\mathrm{CaO}, \mathrm{P}_{2} \mathrm{O}_{5}, \mathrm{~Pb}, \mathrm{Cd}, \mathrm{Cu}, \mathrm{Co}, \mathrm{Cd}, \mathrm{Sn}, \mathrm{Hg}$, Mo, MnO, Sb, Zn reflect industrial activity and $\mathrm{Cr}$, As, Ni, V, $\mathrm{Fe}_{2} \mathrm{O}_{3}, \mathrm{~K}_{2} \mathrm{O}$ distributions are partly controlled by the underlying geology and partly by anthropogenic inputs (Fordyce \& Ander 2003).

These results highlight the importance of a multi-element survey, which determines the major as well as the trace element components of soil as an aid to contaminant source identification.

\section{CONCLUSIONS}

1. The quality of urban land is of increasing concern in the UK and many other countries as the need to reuse brownfield sites and regenerate city environments grows. However, information on the chemical and physical properties of urban soils is often limited as historically these areas were avoided by soil surveys. 
2. Systematic multi-element urban geochemical surveys generate valuable information on the concentration, distribution, sources and likely mobility of potentially harmful elements in city environments providing an overview and framework to more detailed site investigations and can highlight areas for further follow-up in terms of contaminated land.

3. To date, geochemical datasets for up to 48 parameters in urban soils have been generated for 21 cities in the UK by the GSUE project. These data are of direct relevance to a number of legislative drivers including the assessment of sources; pathways and risks to human receptors under the UK contaminated land regulations. The data also have application to the protection of water resources required by the EU Water Framework Directive and to soil quality soon to be addressed by the proposed EU Soils Framework Directive.

4. The BGS is increasingly working with local authorities and environmental protection agencies to develop the applications of the urban geochemical datasets. Major gaps in information include data for $\mathrm{Hg}$ and organic contaminants in the urban environment. It is anticipated that these will be addressed via end-user partnership arrangements in the future.

\section{ACKNOWLEDGEMENTS:}

This paper is published with the permission of the Director of the British Geological Survey (NERC). The authors gratefully acknowledge the contributions of Mick Strutt (sampling), Mark Allen, Mark Ingham, Charlie Gowing and Barbara Vickers 
(analysis) and the many geochemists and students who have worked for BGS on the GSUE project over the past 12 years ensuring a well-founded systematic survey. 


\section{REFERENCES:}

Ander, E. L., Smith, B., FordyCE, F. M. \& Rawlins, B. G. 2001. Trace Elements. In:

D’Arcy, B. J., Ellis, J. B., Ferrier, R. C., Jenkins, A. \& Dils, R. (eds). Diffuse

Pollution Impacts. CIWEM, Terence Dalton Publishers, Lavenham, Surrey, 85-94.

BIRKE, M. \& RAUCH, U. 2000. Urban geochemistry: investigations in the Berlin metropolitan area. Environmental Geochemistry and Health, 22 (3), 233-248.

Blume, H. P. \& Brummer, G. 1991. Prediction of heavy metal behaviour in soil by means of simple field tests. Ecotoxicology and Environmental Safety, 22, 164-174.

BoDEN, A.G. 1994. Methodendokumentation Bodenkunde-Auswertungsmethoden zur Beurteilung der Empfindlichkeit und Belastbarkeit von Boden. (Soil Method Report - Interpretation Methods to Evaluate the Sensitivity and Attenuation Capacity of Soils) Geol.JB. F31. Hanover, Germany.

Breward, N., Green, P. M. \& Henney, P. J. 1992. Analysis and processing of regional geochemical imagery using a Macintosh II microcomputer for geochemical map production. Applied Geochemistry Series, Technical Report WP/92/16. British Geological Survey, Keyworth.

BRIDGE, D. M., BRown, M. J. \& HoOKeR, P. J. 1997. Wolverhampton Urban Environmental Survey: An Integrated Geoscientific Case Study. Technical Report WE/95/49. British Geological Survey, Keyworth. 
British GeOlOGiCAL SuRVEY. 1997. Regional Geochemistry of Northwest England and North Wales. British Geological Survey, Keyworth.

British GeOlOGICAL SURVEY. 2000. Regional Geochemistry of Wales and Part of West-central England: Stream Sediment and Soil. British Geological Survey, Keyworth.

Brown, S. E. 2003. Geochemical Baseline Data for the Urban Area of Cardiff. Internal Report IR/01/102R. British Geological Survey, Keyworth.

Cave, M. R., Wragg, J., Palumbo, B. \& KlincK, B. A. 2003. Measurement of the Bioaccessibility of Arsenic in UK Soils. R\&D Report P5-062/TR/02. Environment Agency, Bristol.

CEC. 1998. Water Quality Framework. EU Directive 98/83/EC. Commission of the European Community, Brussels.

CEC. 2001. Setting Maximum Levels for Certain Contaminants in Foodstuffs. Commission Regulation (EC)466/2001. Commission of the European Community, Brussels.

Chronopoulos, J., Haidouti, C., Chronopoulou-Sereli, A. \& MASSAS, I. 1997. Variations in plant and soil lead and cadmium content in urban parks in Athens, Greece. Science of the Total Environment, 196 (1), 91-98. 
COATS, J. S. \& HARRIS, J. R. 1995. Database design in geochemistry: BGS experience.

In: GILES, J. R. A. (ed.) Geological Data Management. Special Publication 97, Geological Society of London, 25-32.

DAlenberg, J. W. \& VAN DRIEL, W. 1990. Contribution of atmospheric deposition to heavy-metal concentrations in field crops. Netherlands Journal of Agricultural Science, 38, 396-379.

DEFRA-EA. 2002a. Contaminants in Soils: Collation of Toxicological Data and Intake Values for Humans. R\&D Report CLR9. Department of the Environment, Food and Rural Affairs and the Environment Agency, Bristol.

DEFRA-EA. 2002b. Assessment of Risks to Human Health from Land Contamination: An Overview of the Development of the Soil Guideline Values and Related Research. R\&D Report CLR7. Department of the Environment, Food and Rural Affairs and the Environment Agency, Bristol.

DEFRA-EA. 2002c. Contaminated Land Exposure Assessment Model: Technical Basis and Algorithms. R\&D Report CLR10. Department of the Environment, Food and Rural Affairs and the Environment Agency, Bristol.

DEFRA-EA. 2002d. Soil Guideline Values for Arsenic Contamination. R\&D Report SGV1. Department of the Environment, Food and Rural Affairs and the Environment Agency, Bristol. 
DEFRA-EA. 2002e. Soil Guideline Values for Cadmium Contamination. R\&D Report SGV3. Department of the Environment, Food and Rural Affairs and the Environment Agency, Bristol.

DETR 1998. Planning for the Communities of the Future. HMSO, London.

DETR. 2000. Contaminated Land: Implementation of Part IIa of the Environmental Protection Act. HMSO, London

DOE. 1994. Documentary Research on Industrial Sites. R\&D Report CLR3.

Department of the Environment, London.

DOE. 1995. Prioritisation and Categorisation Procedure for Sites, Which May Be Contaminated. Department of the Environment, London.

EA. 1998. Policy and Practice for the Protection of Groundwater. Environment Agency, Bristol.

EA. 2002. The Water Framework Directive. Guiding Principles on the Technical Requirements. Environment Agency, Bristol.

EnVironmental Protection Act Part IIA. 1990. Contaminated Land. HMSO, London. 
Farago, M. E., Kavanagh, P., Blanks, R., Kelly, J. \& 6 Others. 1996. Platinum metal concentrations in urban road dust and soil in the United Kingdom. Fresenius Journal of Analytical Chemistry, 354 (5-6), 660-663.

FARMER, J. G., JOHNSON, L. R. \& LOVELL, M. A. 1989. Urinary arsenic speciation and the assessment of UK dietary, environmental and occupational exposures to arsenic. Environmental Geochemistry and Health, 11 (3-4), 93.

Farmer, J. G., Graham, M. C., ThOMAs, R. P., Licona-Manzur, C. \& 10 Others. 1999. Assessment and modelling of the environmental chemistry and potential for remediative treatment of chromium-contaminated land. Environmental Geochemistry and Health, 21 (4), 331-337.

Fergusson, J. E. 1990. The Heavy Metals: Chemistry, Environmental Impacts and Health Effects. Pergamon Press, Oxford.

FORDYCE, F. M. \& ANDER, E. L. 2003. Urban Soils Geochemistry and GIS-aided Interpretation - A Case Study from Stoke-on-Trent. Internal Report IR/01/35R. British Geological Survey, Keyworth.

Freestone, S. E., O'Donnell, K. E. \& Brown, S. E. 2004. Geochemical Baseline Data for the Urban Area of Mansfield. Internal Report IR/02/082. British Geological Survey, Keyworth. 
Hough, R. L., Breward, N., Young, S. D. Crout, N. M. J., Tye, A. M., Moir, A. M. AND THORNTON, I. 2004. Assessing potential risk of heavy metal exposure from consumption of home-produced vegetables by urban populations. Environmental Health Perspectives, 12 (2), 215-221.

Imperato, M., AdAmo, P., Naimo, D., Arienzo, M., Stanzione, D. \& Violante, P. 2003. Spatial distribution of heavy metals in urban soils of Naples city (Italy). Environmental Pollution, 124 (2), 247-256.

InghaM, M. N. \& VREBOS, B. A. R. 1994. High productivity geochemical XRF analysis. Advances in X-ray Analysis, 37, 717-724.

Johnson, C. C., Brown, S. E. \& Lister, T. R. 2003. G-BASE Field Procedures Manual. Internal Report IR/03/096N. British Geological Survey, Keyworth.

Johnson, C. C., Breward, N., Ander, E. L. \& Ault, L. This Volume. G-BASE: Baseline geochemical mapping of Great Britain and Northern Ireland.

KELLY, J. J. P. 1997. Influence of Geology and Anthropogenic Activity on the Geochemistry of Urban Soils. PhD. Thesis, Imperial College Centre for Environmental Technology, London.

KELLY, J. J. P., THORNTON, I. \& SiMPSON, P. R. 1996. Urban geochemistry: a study of the influence of anthropogenic activity on the heavy metal content of soils in 
traditionally industrial and non-industrial areas of Britain. Applied Geochemistry, 11, 363-370.

LiSTER, T. R. 2002. Analysis of Variance of G-BASE Sub-surface Soil Data from 11 Urban Centres in England and Wales. Internal Report IR/02/0009. British Geological Survey, Keyworth.

McGrath, S. P. \& Loveland, P. J. 1992. Soil Geochemical Atlas of England and Wales. Blackie Academic and Professional, Glasgow.

McMillan, A. A., Ellison, R. A., Fordyce, F. M., Golledge, N. R. \& 7 Others. 2001. Superficial Deposits Characterisation in the Urban Environment; A Best Practice Guide to Mapping and Research. Internal Report IR/01/68. British Geological Survey, Keyworth.

Mertz, W. (ed.) 1986. Trace Elements in Human and Animal Nutrition. Academic Press, New York.

Mielke, H. W., Gonzales, C. R., Smith, M. K. \& MielKe, P. W. 2000. Quantities and associations of lead, zinc, cadmium, manganese, chromium, nickel, vanadium, and copper in fresh Mississippi delta alluvium and New Orleans alluvial soils. Science of the Total Environment, 246 (2-3), 249-259.

MielKe, H., Dugas, D., Mielke, P., Smith, K., Smith, S. \& GonZales, C. 1997. Associations between soil lead and childhood blood lead in urban New Orleans and 
rural Lafourche Parish of Louisiana. Environmental Health Perspectives, 105 (9), 950-954.

MoIR, A. M. \& ThORNTON, I. 1989. Lead and cadmium in urban allotment and garden soils and vegetables in the United Kingdom. Environmental Geochemistry and Health, 11 (3-4), 113-119.

MonACI, F. \& BARGAGLI, R. 1997. Barium and other trace metals as indicators of vehicle emissions. Water, Air and Soil Pollution, 100 (1-2), 89-98.

Monaci, F., Moni, F., LAnciotti, E., Grechi, D. \& BARgagli, R. 1999.

Biomonitoring of airborne metals in urban environments: new tracers of vehicle emission, in place of lead. Environmental Pollution, 107, 321-327.

Morley, S. E. \& Ferguson, A. J. 2001. Geochemical Baseline Data for the Urban Area of Swansea. Internal Report IR/01/036R. British Geological Survey, Keyworth.

Nathanial, C. P., Ferguson, C. C., Brown, M. J. \& Hooker, P. J. 1997. Mapping the Risks to Human Health from Urban Soils. Report. Nottingham Trent University, Nottingham.

O'DonnelL, K. E. 2004. Geochemical Baseline Data for the Urban Area of York. Internal Report IR/02/085. British Geological Survey, Keyworth. 
PALMER, R.C. \& LEWIS, M.A. 1998. Assessment of groundwater vulnerability in England and Wales. In: Robins, N. S. (ed) Groundwater Pollution, Aquifer Vulnerability and Recharge. Geological Society, London. 191-198.

Palumbo, B., Rawlins, B. G., Herbert, C., Kessler, H. \& KlincK, B. 2004. Human Health Risk Assessment for Exposure to Soil in Allotments, Coventry (UK). Commissioned Report CR/04/045N. British Geological Survey, Keyworth.

PATERSON, E., SANKA, M. \& CLARK, L. 1996. Urban soils as pollutant sinks - a case study from Aberdeen, Scotland. Applied Geochemistry, 11 (1-2), 129-131.

Peltola, P. \& Astrom, M. 2003. Urban geochemistry: A multimedia and multielement survey of a small town in northern Europe. Environmental Geochemistry and Health, 25 (4), 397-419.

Petkov, P., Palichev, T. \& Dimitrov, A. 1999. A study of the mechanism of action of antismoke additives for diesel fuels. Oxidation Communications, 22 (2), 194-206.

Plant, J. A. 1973. A random numbering system for geochemical samples. Transactions of the Institute of Mining and Metallurgy, B82, 63-66.

Plant, J. A. JefFrey, K. Gill, E. \& FAGe, C. 1975. The systematic determination of accuracy and precision in geochemical exploration data. Journal of Geochemical Exploration. 4 (4), 467-486. 
Rawlins, B. G. \& Brown, S. E. 2003. Assessing Geostatistical Methods for Presenting Urban Soil Geochemical Data from Coventry. Internal Report IR/03/012. British Geological Survey, Keyworth.

Rieunerts, J. S., Thornton, I., FARAgo, M. E. \& Ashmore, M. R. 1998. Factors influencing metal bioavailability in soils: preliminary investigations for the development of a critical loads approach for metals. Chemical Speciation and Bioavailability, 10 (2), 61-75.

RowelL, D. L. 1994. Soil Science: Methods and Applications. Longman Scientific and Technical, London.

Ruby, M. V., Davis, A., Schoof, R., Eberle, S. \& Sellstone, C. M. 1996.

Estimation of lead and arsenic bioavailability using a physiological based extraction test. Environmental Science and Technology, 30, 422-430.

SAlminen, R., TARVAinen, T., Demetriades, A., Duris, M. \& 24 Others. 1998. FOREGS Geochemical Mapping Field Manual. Guide 47. Geological Survey of Finland, Espoo.

SAnCheZ-Martin, M. J., SAnChez-CAMAZANo, M. \& Lorenzo, L. F. 2000.

Cadmium and lead contents in suburban and urban soils from two medium-sized cities of Spain: Influence of traffic intensity. Bulletin of Environmental Contamination and Toxicology, 64 (2), 250-257. 
SAS InSTITUTE INC. 1989. SAS Language and Procedures; Usage. SAS Institute Inc. Cary, NC.

SnedeCor, G.W. \& Cochran, W.G. 1989. Statistical Methods. Iowa State University Press, Ames, IA.

Thornton, I., WAtt, J. M., Davies, D. J. A., Hunt, A., Cotterhowells, J. \& JoHNSON, D. L. 1994. Lead contamination of UK dusts and soils and implications for childhood exposure - an overview of the work of the Environmental Geochemistry Research Group, Imperial College, London, England 1981 - 1992. Environmental Geochemistry and Health, 16 (3-4), 113-122.

Thornton, I., Culbard, E., MoOrcroft, S., WAtT, J., WheAtley, M., ThOMson, M., \& ThOMAs, J. F. A. 1985. Metals in urban dusts and soils. Environmental Technology Letters 6 (4), 137-144.

Tijhuis, L., BrattLi, B. \& SAEther, O. M. 2002. A geochemical survey of topsoil in the city of Oslo, Norway. Environmental Geochemistry and Health, 24 (1), 67-94.

WANG, Y., THORNTON, I. \& FARAGO, M. 1997. Changes in lead concentrations in the home environment in Birmingham, England over the period 1984-1996. Science of the Total Environment, 207 (2-3), 149-156.

WHO. 1996. Trace Elements in Human Nutrition and Health. World Health Organisation, Geneva. 
Wilson, A. A., Rees, J. G., Crofts, R. G., Howard, A. S, Buchanan, J. G \& Waine, P. J. 1992. Stoke on Trent: A Geological Background for Planning and Development. Technical Report WA/91/01. British Geological Survey, Keyworth.

WONG, J. W. C. 1996. Heavy metal contents in vegetables and market garden soils in Hong Kong. Environmental Technology, 17 (4), 407-414. 
LIST OF TABLES:

Table 1 List of parameters currently determined in urban soils by the GSUE project

Table 2 Percentage of variance in surface soil samples $(0.20 \mathrm{~m})$ from 11 urban centres attributable to between-site, between-sample and residual variance

Table 3 Summary statistics for selected total element concentrations in surface soils $(0.20 \mathrm{~m})$ in $14 \mathrm{UK}$ urban areas

Table 4 Summary statistics for selected total element concentrations in rural and urban soils from Stoke-on-Trent

Table 5 Ratio of urban/rural median element concentrations in deeper $(0.50 \mathrm{~m})$ soils over each 1: 625000 scale superficial deposit and 1: 250000 scale solid geology unit in the Stoke-on-Trent area

Table 6 Element associations indicative of various made ground types and major controls on elements in soils from Stoke-on-Trent 


\section{LIST OF FIGURES:}

Figure 1 Locations of the 21 UK urban centres sampled to date by the GSUE project

Figure 2 Diagram of the GSUE composite soil sampling strategy

Figure 3 Interpolated map of total $\mathrm{Pb}$ in deeper soils $(0.50 \mathrm{~m})$ from the Wolverhampton region

Figure 4 Graduated symbol map of total As in 747 surface soils $(0.20 \mathrm{~m})$ from Stokeon-Trent

Figure 5 Concept of source, pathway and receptor in the assessment of contaminated land

Figure 6 Locations where total As in 747 surface soils $(0.20 \mathrm{~m})$ exceed the $20 \mathrm{mg} / \mathrm{kg}$ CLEA SGV in Stoke-on-Trent

Figure 7 Box and whisker plots of the $10^{\text {th }}, 25^{\text {th }}, 50^{\text {th }}, 75^{\text {th }}$ and $90^{\text {th }}$ percentiles of total As concentrations in surface soils $(0.20 \mathrm{~m})$ from $13 \mathrm{UK}$ cities

Figure 8 (a) Concentrations of total Cd in deeper (0.50 m) soils and (b) Cd soil attenuation capacity across Stoke-on-Trent 
Figure 9 Box and whisker plots of the $5^{\text {th }}, 25^{\text {th }}, 50^{\text {th }}, 75^{\text {th }}$ and $95^{\text {th }}$ percentiles of total Cu concentrations in surface soils $(0.20 \mathrm{~m})$ from 7 urban areas and surrounding rural soils of the Humber-Trent region

Figure 10 Total concentrations of selected elements in deeper $(0.50 \mathrm{~m})$ soils over different rock types in the rural and urban environment of Stoke-on-Trent

Figure 11 Bar chart showing the median of total concentrations of selected elements in surface soils $(0.20 \mathrm{~m})$ from Stoke-on-Trent, Swansea, Cardiff and Telford urban centres

Figure 12 Total Sn concentrations in surface soils $(0.20 \mathrm{~m})$ from the Hull region

Figure 13 Box and whisker plots of the $10^{\text {th }}, 25^{\text {th }}, 50^{\text {th }}, 75^{\text {th }}$ and $90^{\text {th }}$ percentiles of total As distribution in deeper $(0.50 \mathrm{~m})$ soils from Stoke-on-Trent categorised on the basis of underlying made ground type 
Table 1 List of parameters currently determined in urban soils by the GSUE project

\begin{tabular}{ll}
\hline Analytical Method & List of Determinands \\
\hline XRFS & $\mathrm{Ag}, \mathrm{Al}_{2} \mathrm{O}_{3}, \mathrm{As}, \mathrm{Ba}, \mathrm{Bi}, \mathrm{Br}, \mathrm{CaO}, \mathrm{Cd}, \mathrm{Ce}$, \\
& $\mathrm{Co}, \mathrm{Cr}, \mathrm{Cs}, \mathrm{Cu}, \mathrm{Fe}_{2} \mathrm{O}_{3}, \mathrm{Ga}, \mathrm{Ge}, \mathrm{Hf}, \mathrm{I}, \mathrm{K}_{2} \mathrm{O}$, \\
& $\mathrm{La}, \mathrm{MgO}, \mathrm{MnO}, \mathrm{Mo}^{\mathrm{N}} \mathrm{Na}_{2} \mathrm{O}, \mathrm{Nb}, \mathrm{Ni}, \mathrm{P}_{2} \mathrm{O}_{5}$, \\
& $\mathrm{Pb}, \mathrm{Rb}, \mathrm{Sb}, \mathrm{Sc}, \mathrm{Se}, \mathrm{SiO}_{2}, \mathrm{Sn}, \mathrm{Sr}, \mathrm{Ta}, \mathrm{Te}$, \\
& $\mathrm{Th}, \mathrm{TiO}_{2}, \mathrm{TI}, \mathrm{U}, \mathrm{V}, \mathrm{W}, \mathrm{Y}, \mathrm{Zn}, \mathrm{Zr}$ \\
$\mathrm{CaCl}_{2} .2 \mathrm{H}_{2} \mathrm{O}$ Slurry & $\mathrm{pH}$ \\
$\mathrm{Heating}^{\circ} 450^{\circ} \mathrm{C}$ & Loss on Ignition \\
\hline
\end{tabular}


Table 2 Percentage of variance in surface soil samples $(0.20 \mathrm{~m})$ from 11 urban centres attributable to between-site, between-sample and residual variance

\begin{tabular}{|c|c|c|c|}
\hline & $\begin{array}{l}\text { Between } \\
\text { site } \\
(\%)\end{array}$ & $\begin{array}{l}\text { Between } \\
\text { sample } \\
\text { (\%) }\end{array}$ & $\begin{array}{l}\text { Residual } \\
\text { (\%) }\end{array}$ \\
\hline $\mathrm{TiO}_{2}$ & 97.44 & 2.17 & 0.39 \\
\hline $\mathrm{MnO}$ & 93.87 & 6.05 & 0.07 \\
\hline $\mathrm{Fe}_{2} \mathrm{O}_{3}$ & 89.81 & 10.10 & 0.08 \\
\hline V & 97.67 & 2.29 & 0.03 \\
\hline $\mathrm{Cr}$ & 94.94 & 3.53 & 1.51 \\
\hline Co & 99.31 & 0.31 & 0.37 \\
\hline $\mathrm{Ni}$ & 98.46 & 1.37 & 0.16 \\
\hline $\mathrm{Cu}$ & 80.93 & 18.50 & 0.56 \\
\hline $\mathrm{Zn}$ & 98.38 & 1.61 & 0.01 \\
\hline As & 98.79 & 1.14 & 0.06 \\
\hline Mo & 98.12 & 1.70 & 0.17 \\
\hline $\mathrm{Ba}$ & 98.15 & 1.39 & 0.45 \\
\hline $\mathrm{Pb}$ & 97.67 & 1.99 & 0.33 \\
\hline U & 80.16 & 2.7 & 17.09 \\
\hline $\mathrm{Cd}$ & 47.88 & 6.7 & 45.34 \\
\hline Sn & 83.10 & 5.54 & 11.35 \\
\hline $\mathrm{Sb}$ & 89.20 & 6.22 & 4.57 \\
\hline
\end{tabular}

ANOVA based on 37 replicate pairs except Cd (27); Mo (33); Sb (16) All data log transformed 
Table 3 Summary statistics for selected total element concentrations in surface soils $(0.20 \mathrm{~m})$ in 14 UK urban areas

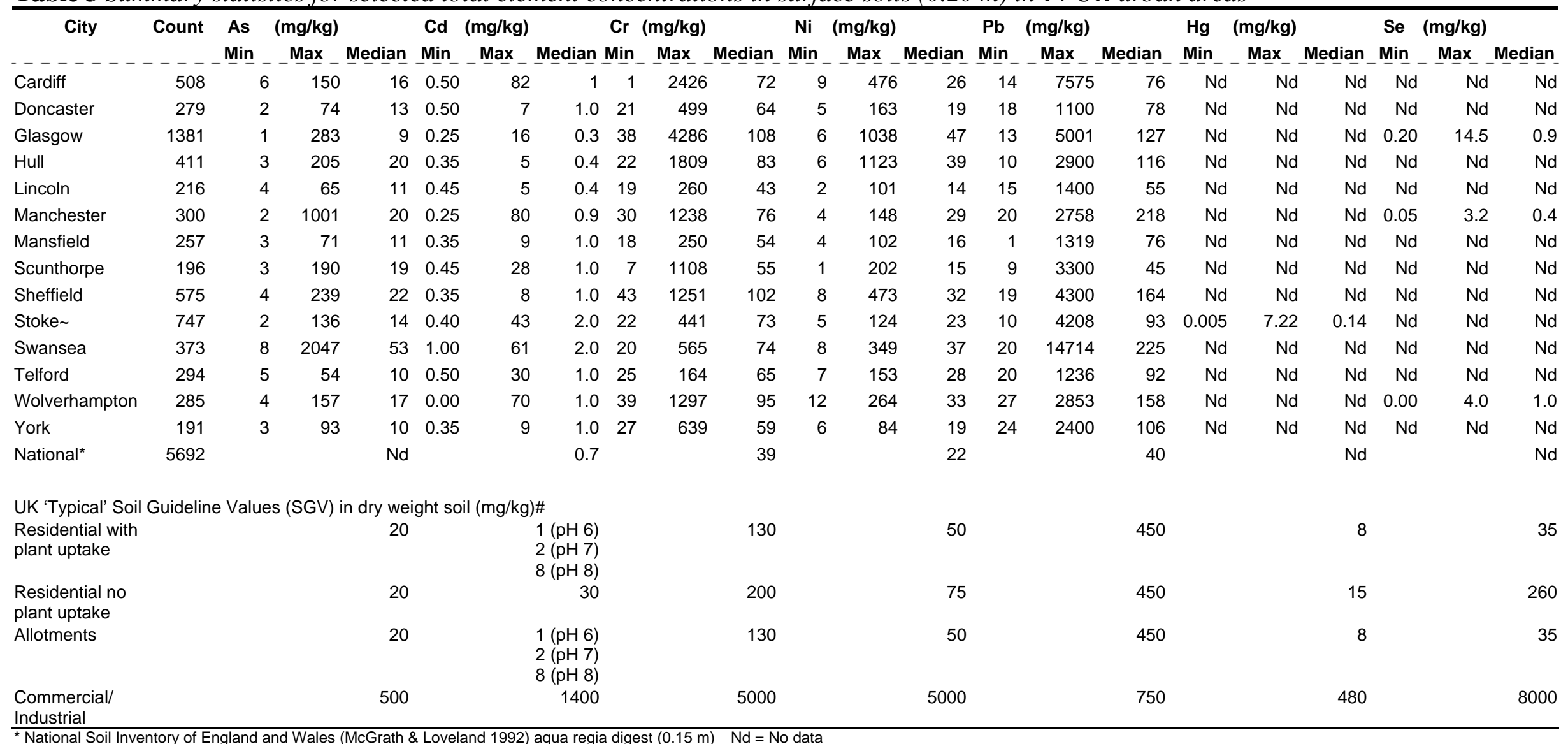

* National Soil Inventory of England and Wales (McGrath \& Loveland 1992) aqua regia digest $(0.15 \mathrm{~m}) \quad \mathrm{Nd}=$ No data

$\sim \mathrm{Hg}$ is not routinely analysed in the GSUE survey but determinations in surface soils from Stoke were carried out by digestion of $1 \mathrm{~g}$ of milled sample in aqua-regia and analysis by cold vapour atomic absorption spectrometry

\# DEFRA-EA (2002b) Typical soil guideline values (SGV) derived from the UK CLEA contaminated land assessment model 
Table 4 Summary statistics for selected total element concentrations in rural and urban soils from Stoke-on-Trent

\begin{tabular}{|c|c|c|c|c|c|c|c|c|}
\hline Statistics & Soil Type & $\begin{array}{c}\text { As } \\
(\mathrm{mg} / \mathrm{kg})\end{array}$ & $\begin{array}{c}\text { Cd } \\
(\mathrm{mg} / \mathrm{kg})\end{array}$ & $\begin{array}{c}\mathrm{Cr} \\
(\mathrm{mg} / \mathrm{kg})\end{array}$ & $\begin{array}{c}\mathrm{Ni} \\
(\mathrm{mg} / \mathrm{kg})\end{array}$ & $\begin{array}{c}\mathrm{Pb} \\
(\mathrm{mg} / \mathrm{kg})\end{array}$ & $\begin{array}{c}\text { Sn } \\
(\mathrm{mg} / \mathrm{kg})\end{array}$ & $\begin{array}{c}\mathrm{Zn} \\
(\mathrm{mg} / \mathrm{kg})\end{array}$ \\
\hline \multirow[t]{3}{*}{ Minimum } & Urban A & 2 & 0.4 & 22.0 & 5.0 & 10 & 1 & $\overline{6}$ \\
\hline & Urban S & 4 & 0.4 & 41.0 & 6.0 & 15 & 2 & 20 \\
\hline & Rural S & 4 & 1.0 & 23.0 & 5.0 & 9 & 1 & 13 \\
\hline \multirow[t]{3}{*}{ Maximum } & Urban A & 136 & 43.0 & 441.0 & 124.0 & 4208 & 662 & 2589 \\
\hline & Urban S & 167 & 408.0 & 574.0 & 250.0 & 4207 & 657 & 7408 \\
\hline & Rural S & 47 & 6.0 & 116.0 & 86.0 & 301 & 72 & 1032 \\
\hline \multirow[t]{3}{*}{ Mean } & Urban A & 16 & 1.7 & 76.3 & 27.1 & 176 & 17 & 156 \\
\hline & Urban S & 18 & 1.4 & 94.9 & 34.6 & 164 & 14 & 170 \\
\hline & Rural S & 14 & 1.1 & 72.1 & 23.9 & 57 & 5 & 93 \\
\hline \multirow[t]{3}{*}{ Median } & Urban A & 14 & 2.0 & 73.0 & 23.0 & 93 & 7 & 108 \\
\hline & Urban S & 14 & 0.4 & 92.0 & 30.0 & 61 & 6 & 90 \\
\hline & Rural S & 13 & 1.0 & 72.0 & 23.0 & 47 & 5 & 80 \\
\hline
\end{tabular}


Table 5 Ratio of urban/rural median element concentrations in deeper soils $(0.50 \mathrm{~m})$ over each 1: 625000 scale superficial deposit and 1: 250000 scale solid geology unit in the Stoke-on-Trent area

\begin{tabular}{|c|c|c|c|c|c|c|c|c|c|c|c|c|c|c|c|c|c|c|c|}
\hline Parent Material & MnO & $\mathrm{Fe}_{2} \mathrm{O}_{3}$ & $\mathbf{v}$ & $\mathrm{Cr}$ & Co & $\mathbf{B a}$ & $\mathrm{Ni}$ & $\mathrm{Cu}$ & $\mathrm{Zn}$ & As & Mo & $\mathbf{P b}$ & $\mathbf{u}$ & Sn & Sb & MgO & $\mathrm{P}_{2} \mathrm{O}_{5}$ & $\mathrm{~K}_{2} \mathrm{O}$ & $\mathrm{CaO}$ \\
\hline Alluvium & 2.0 & 1.8 & 1.4 & 1.5 & 1.7 & 1.1 & 1.9 & 1.8 & 1.6 & 0.9 & 1.9 & 1.6 & 1.0 & 1.4 & 1.0 & 0.8 & 0.8 & 0.9 & 1.0 \\
\hline Boulder Clay & 1.6 & 1.3 & 1.3 & 1.2 & 1.3 & 1.1 & 1.2 & 1.5 & 1.0 & 1.2 & 2.6 & 1.4 & 1.1 & 1.3 & 1.0 & 0.7 & 0.9 & 0.6 & 0.5 \\
\hline Glacial Sand and Gravel & 1.0 & 1.9 & 1.4 & 1.4 & 1.4 & 1.4 & 1.5 & 3.0 & 1.3 & 1.6 & 8.5 & 2.3 & 0.8 & 1.5 & 2.5 & 0.6 & 0.8 & 0.9 & 0.7 \\
\hline River Terrace & 2.7 & 1.8 & 1.5 & 1.2 & 1.8 & 1.5 & 1.4 & 2.5 & 2.9 & 1.5 & 1.6 & 2.4 & 1.0 & 2.8 & 1.0 & 0.2 & 0.8 & 0.5 & 1.1 \\
\hline Mercia Mudstone & 1.4 & 1.2 & 1.1 & 1.1 & 1.2 & 1.0 & 1.1 & 1.2 & 1.1 & 1.1 & 2.3 & 1.2 & 1.0 & 1.2 & 1.0 & 0.5 & 0.7 & 0.8 & 0.4 \\
\hline Sherwood Sandstone & 1.3 & 0.9 & 0.9 & 1.0 & 1.0 & 1.0 & 1.0 & 1.4 & 1.2 & 0.8 & 1.2 & 1.0 & 1.0 & 1.2 & 1.0 & 0.7 & 0.8 & 0.8 & 0.3 \\
\hline Salop Formation & 1.5 & 1.3 & 1.0 & 1.1 & 1.2 & 1.0 & 1.0 & 1.3 & 1.1 & 1.1 & 2.3 & 1.4 & 1.0 & 1.5 & 1.0 & 0.7 & 1.2 & 1.0 & 0.4 \\
\hline Westphalian & 1.2 & 1.2 & 1.1 & 1.2 & 1.2 & 1.2 & 1.2 & 1.2 & 1.1 & 1.1 & 1.4 & 1.1 & 1.0 & 1.2 & 1.0 & 0.7 & 1.0 & 0.9 & 0.6 \\
\hline Millstone Grit & 0.9 & 1.0 & 1.3 & 1.3 & 1.0 & 0.8 & 1.1 & 0.7 & 0.7 & $\mathrm{Nd}$ & 2.0 & 0.7 & $\mathrm{Nd}$ & 0.9 & $\mathrm{Nd}$ & 0.7 & $\mathrm{Nd}$ & 0.9 & 4.0 \\
\hline
\end{tabular}

$\mathrm{Nd}=$ No data 
Table 6 Element associations indicative of various made ground types and major controls on elements in soils from Stoke-on-Trent

\begin{tabular}{|c|c|}
\hline Source & Element Association \\
\hline Coal Measures & As, $\mathrm{V}, \mathrm{Mo}, \mathrm{Ni}, \mathrm{Cu}, \mathrm{Zn}, \mathrm{Pb}, \mathrm{CaO}$ \\
\hline $\begin{array}{l}\text { Coal spoil/ } \\
\text { coal ash waste }\end{array}$ & $\begin{array}{l}\mathrm{Fe}_{2} \mathrm{O}_{3}, \mathrm{CaO}, \mathrm{MgO}, \mathrm{K}_{2} \mathrm{O}, \mathrm{Al}_{2} \mathrm{O}_{3}, \mathrm{SiO}_{2} \\
\mathrm{As}, \mathrm{Hg}, \mathrm{V}, \mathrm{Ni}, \mathrm{Cr}, \mathrm{Zn}, \mathrm{Cu}, \mathrm{Cd}, \mathrm{Ba}, \mathrm{Pb}\end{array}$ \\
\hline $\begin{array}{l}\text { Ironworks slag/ } \\
\text { former steel works }\end{array}$ & $\begin{array}{l}\mathrm{Fe}_{2} \mathrm{O}_{3}, \mathrm{Ni}, \mathrm{Cr}, \mathrm{Sn}, \mathrm{Mo}, \mathrm{Cd}, \mathrm{V}, \mathrm{Cu}, \mathrm{Zn} \\
\mathrm{MgO}, \mathrm{P}_{2} \mathrm{O}_{5} \mathrm{CaO}\end{array}$ \\
\hline $\begin{array}{l}\text { Pigments/ } \\
\text { ceramic glazes }\end{array}$ & $\begin{array}{l}\mathrm{Cd}, \mathrm{Cr}, \mathrm{Cu}, \mathrm{Co}, \mathrm{Fe}, \mathrm{Mn}, \mathrm{Ni}, \mathrm{U}, \mathrm{V}, \mathrm{SiO}_{2} \\
\mathrm{Al}_{2} \mathrm{O}_{3}, \mathrm{CaO}, \mathrm{Sn}, \mathrm{Pb}\end{array}$ \\
\hline Control & Element \\
\hline Geological processes & $\mathrm{Al}_{2} \mathrm{O}_{3}, \mathrm{SiO}_{2}, \mathrm{TiO}_{2}, \mathrm{MgO}$ \\
\hline Anthropogenic processes & $\mathrm{CaO}, \mathrm{P}_{2} \mathrm{O}_{5}, \mathrm{~Pb}, \mathrm{Cd}, \mathrm{Cu}, \mathrm{Co}, \mathrm{Cd}, \mathrm{Sn}, \mathrm{Hg}, \mathrm{Mo}, \mathrm{MnO}, \mathrm{Sb}, \mathrm{Zn}$ \\
\hline $\begin{array}{l}\text { Geological and anthropogenic } \\
\text { processes }\end{array}$ & $\mathrm{Cr}, \mathrm{As}, \mathrm{Ni}, \mathrm{V}, \mathrm{Fe}_{2} \mathrm{O}_{3}, \mathrm{~K}_{2} \mathrm{O}$ \\
\hline
\end{tabular}


Figure 1 Locations of the 21 UK urban centres sampled to date by the GSUE project

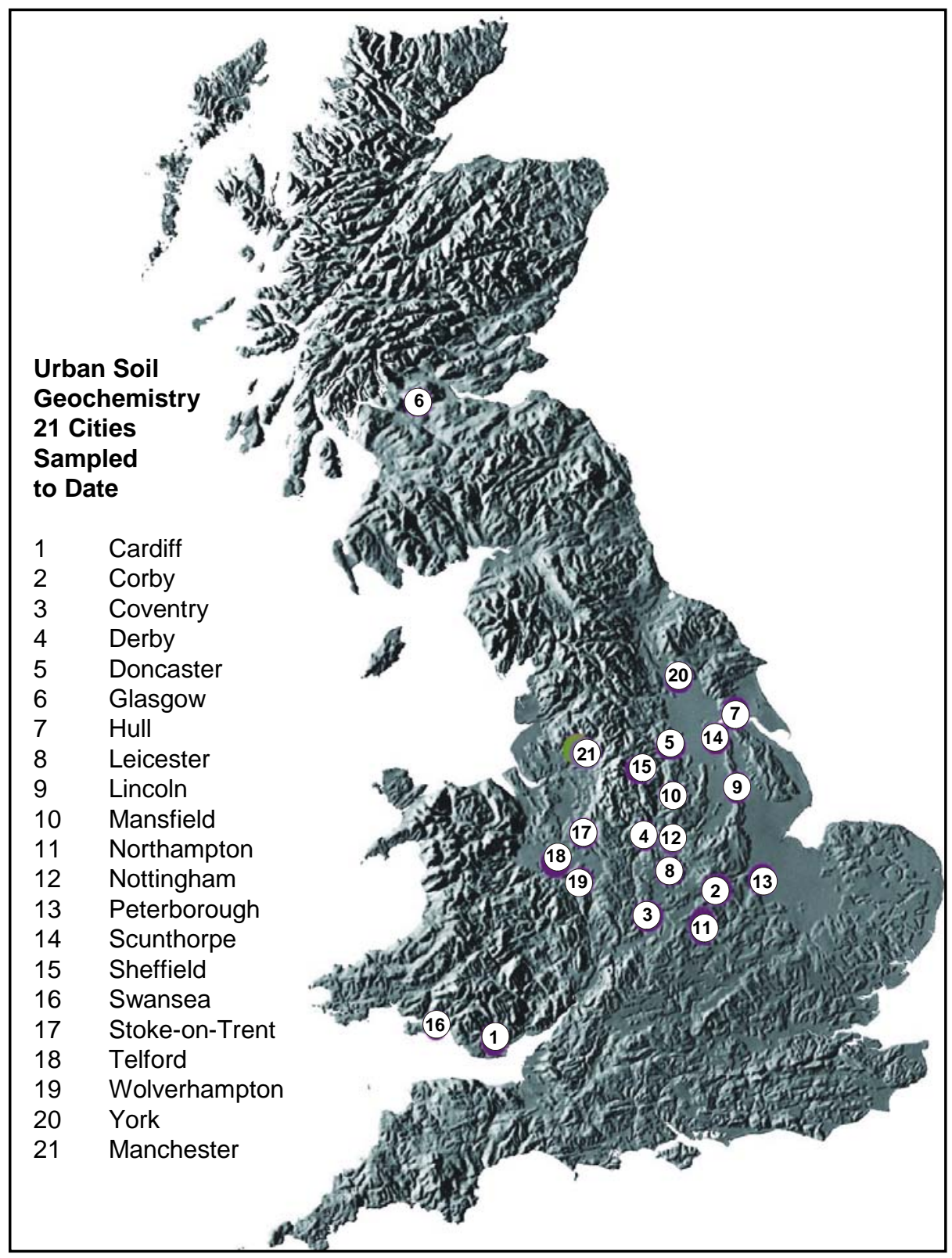


Figure 2 Diagram of the GSUE composite soil sampling strategy

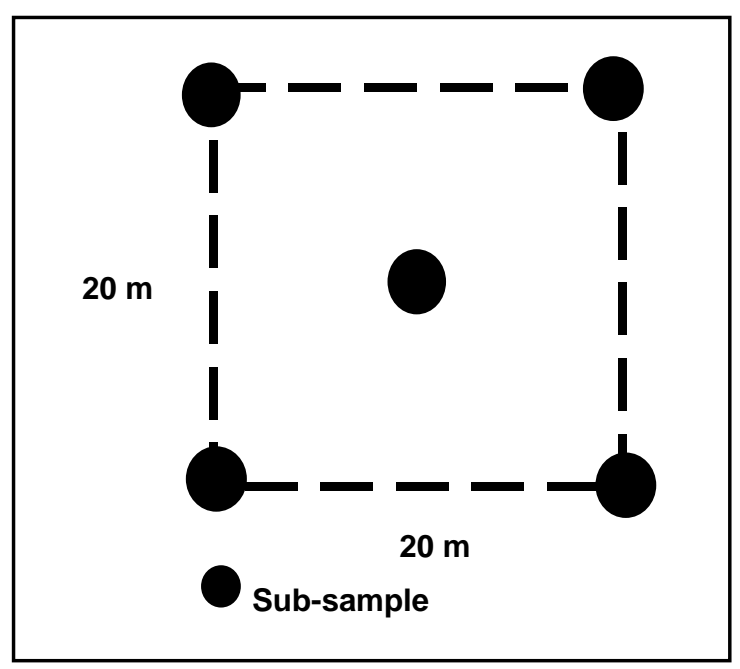


Figure 3 Interpolated map of total $\mathrm{Pb}$ in deeper soils $(0.50 \mathrm{~m})$ from the Wolverhampton region

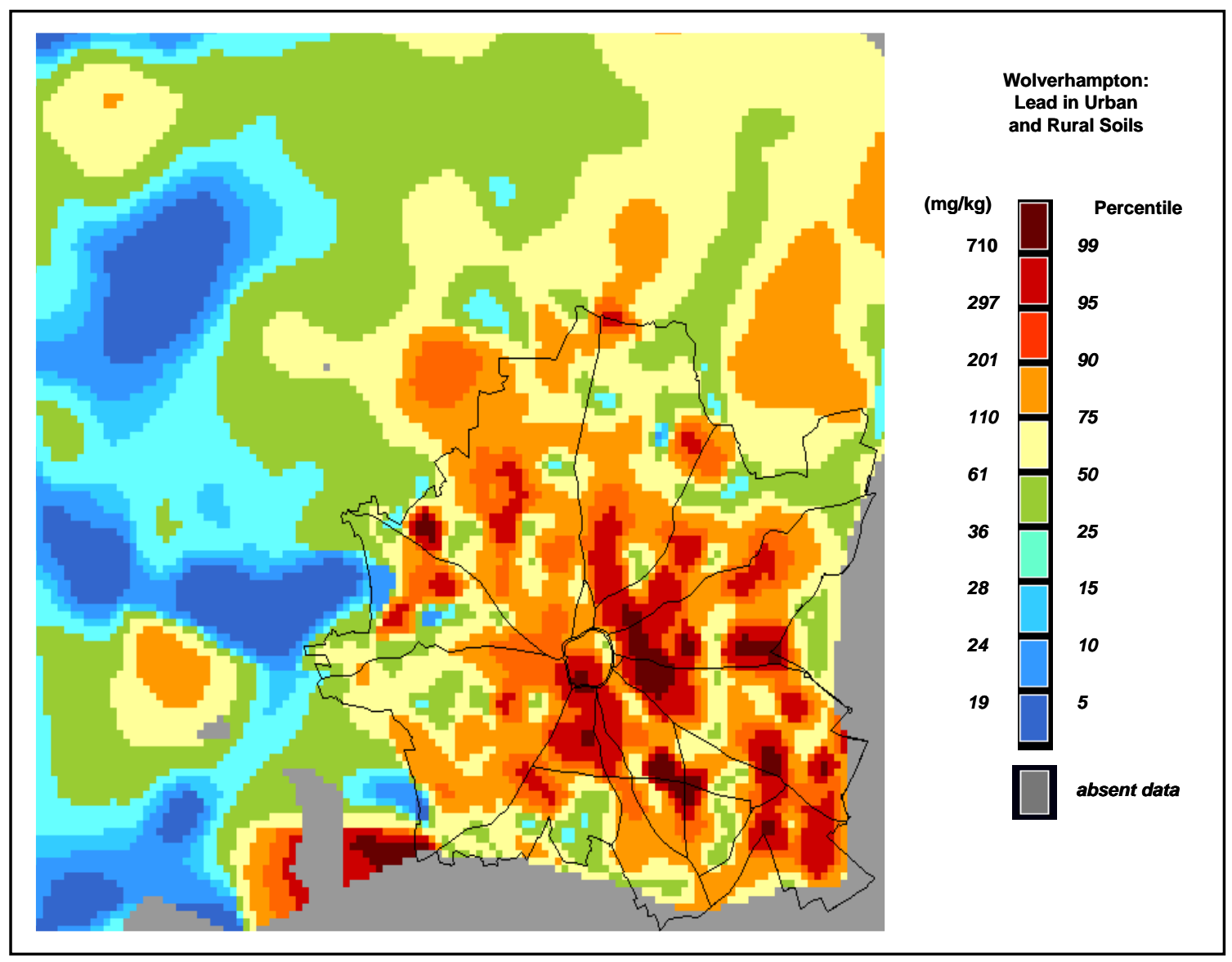


Figure 4 Graduated symbol map of total As in 747 surface soils $(0.20 \mathrm{~m})$ from Stokeon-Trent

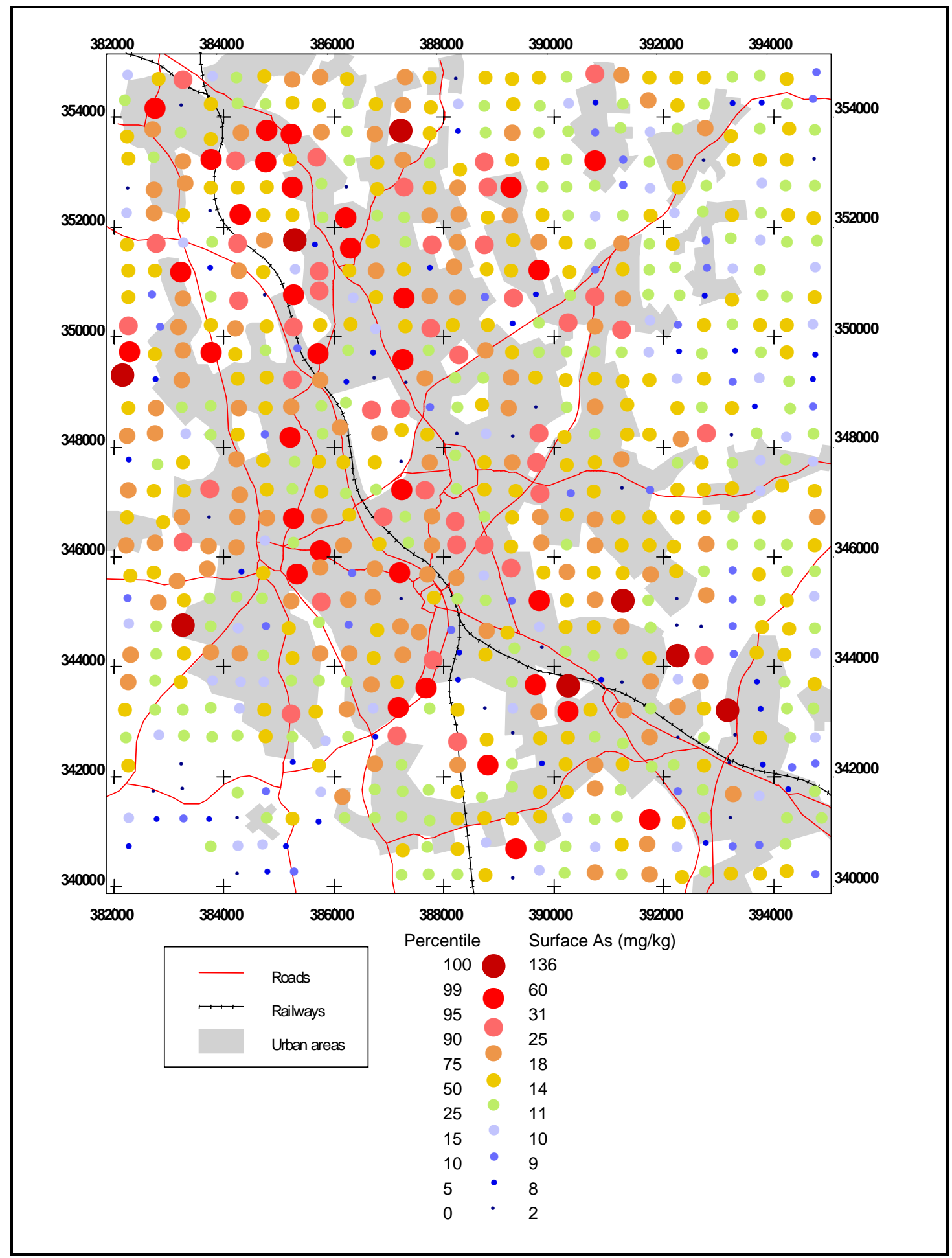


Figure 5 Concept of source, pathway and receptor in the assessment of contaminated land

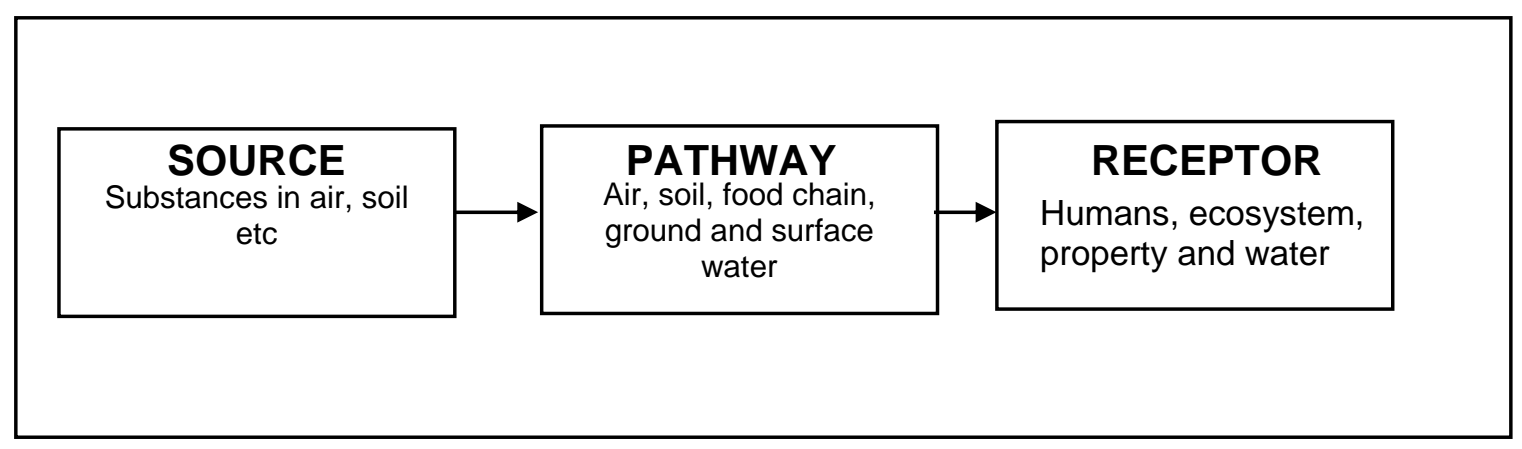


Figure 6 Locations where total As in 747 surface soils $(0.20 \mathrm{~m})$ exceed the $20 \mathrm{mg} / \mathrm{kg}$ CLEA SGV in Stoke-on-Trent

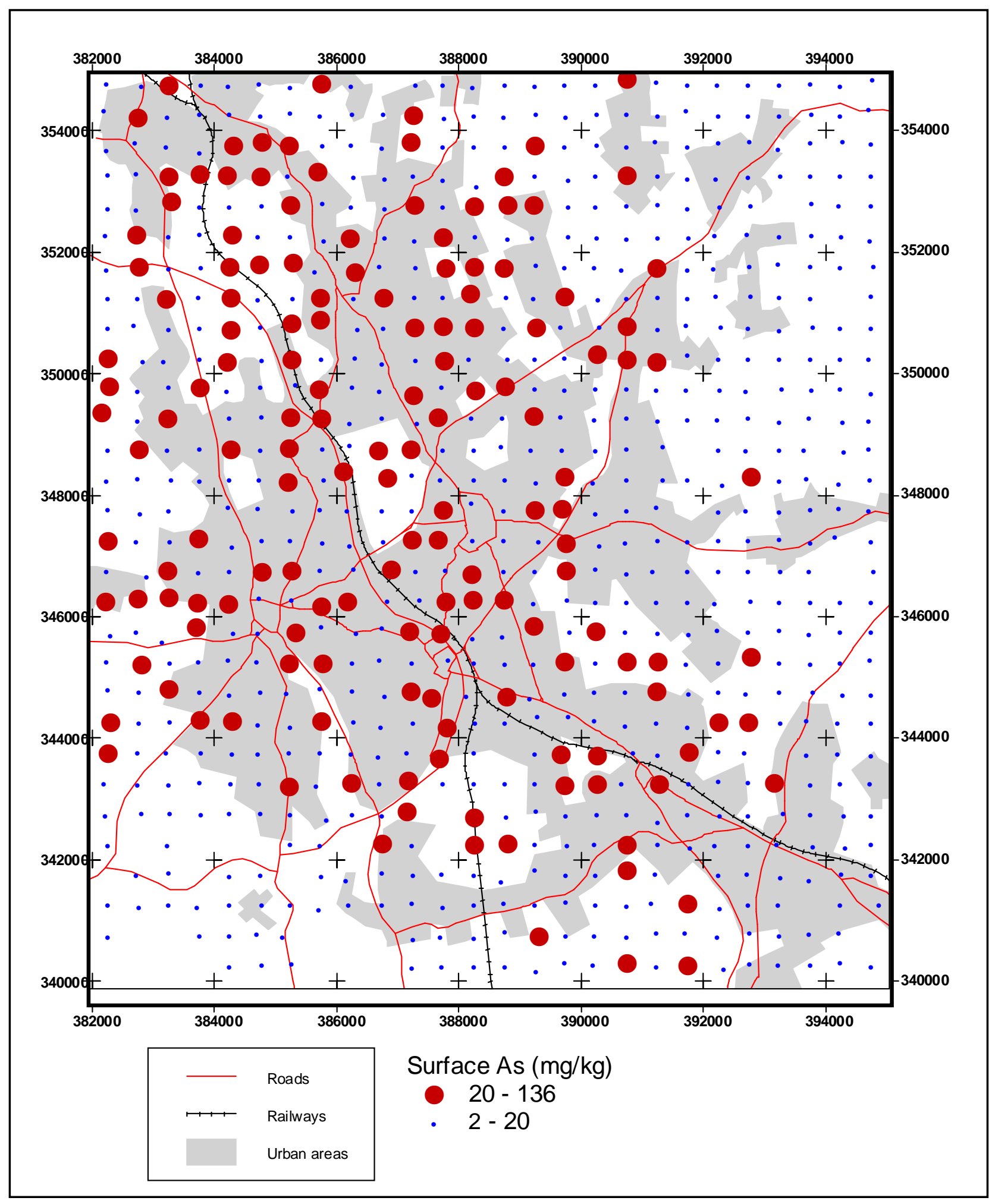


Figure 7 Box and whisker plots of the $10^{\text {th }}, 25^{\text {th }}, 50^{\text {th }}, 75^{\text {th }}$ and $90^{\text {th }}$ percentiles of total As concentrations in surface soils $(0.20 \mathrm{~m})$ from 13 UK cities

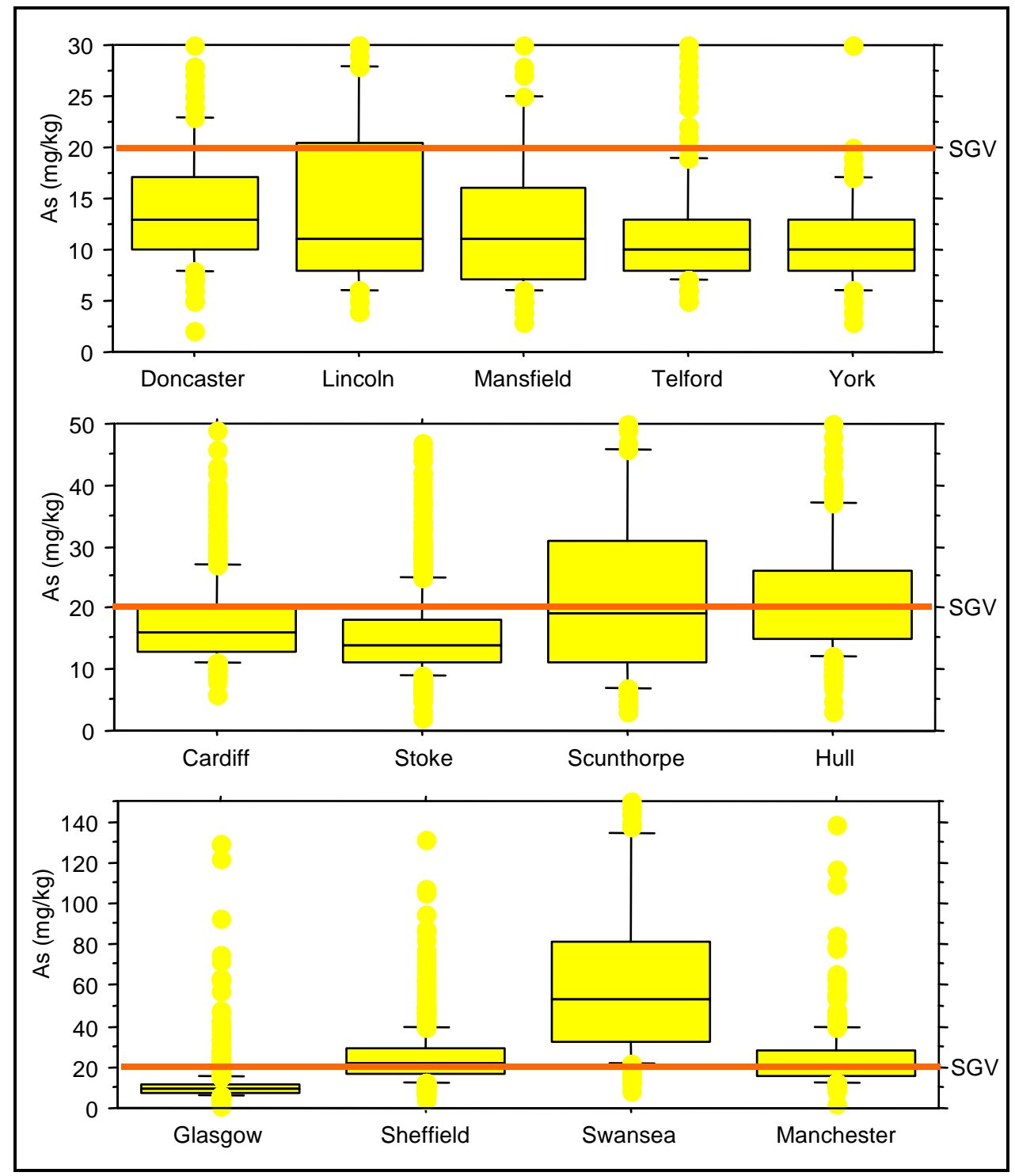

Line and SGV = CLEA soil guideline value for As in soils in residential areas $20 \mathrm{mg} / \mathrm{kg}$ (DEFRA-EA 2002d)

The plots are maximised to display up to the $90^{\text {th }}$ percentile of the distribution therefore some highly anomalous values are not shown $\quad$ For numbers of samples see Table 3 
Figure 8 (a) Total concentrations of Cd in deeper $(0.50 \mathrm{~m})$ soils and (b) Cd soil attenuation capacity across Stoke-on-Trent.

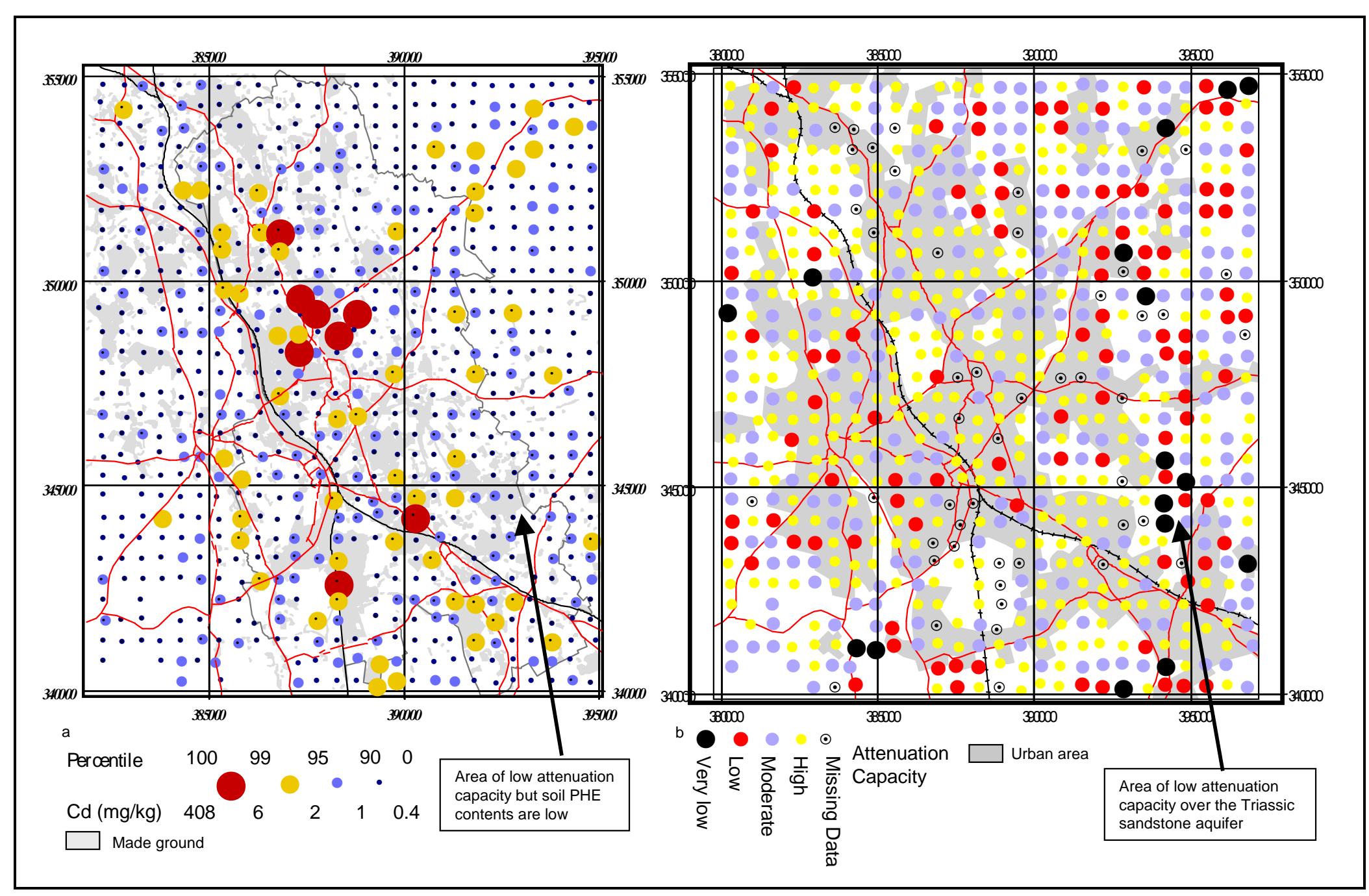


Figure 9 Box and whisker plots of the $5^{\text {th }}, 25^{\text {th }}, 50^{\text {th }}, 75^{\text {th }}$ and $95^{\text {th }}$ percentiles of total Cu concentrations in surface soils $(0.20 \mathrm{~m})$ from 7 urban areas and surrounding rural soils of the Humber-Trent region

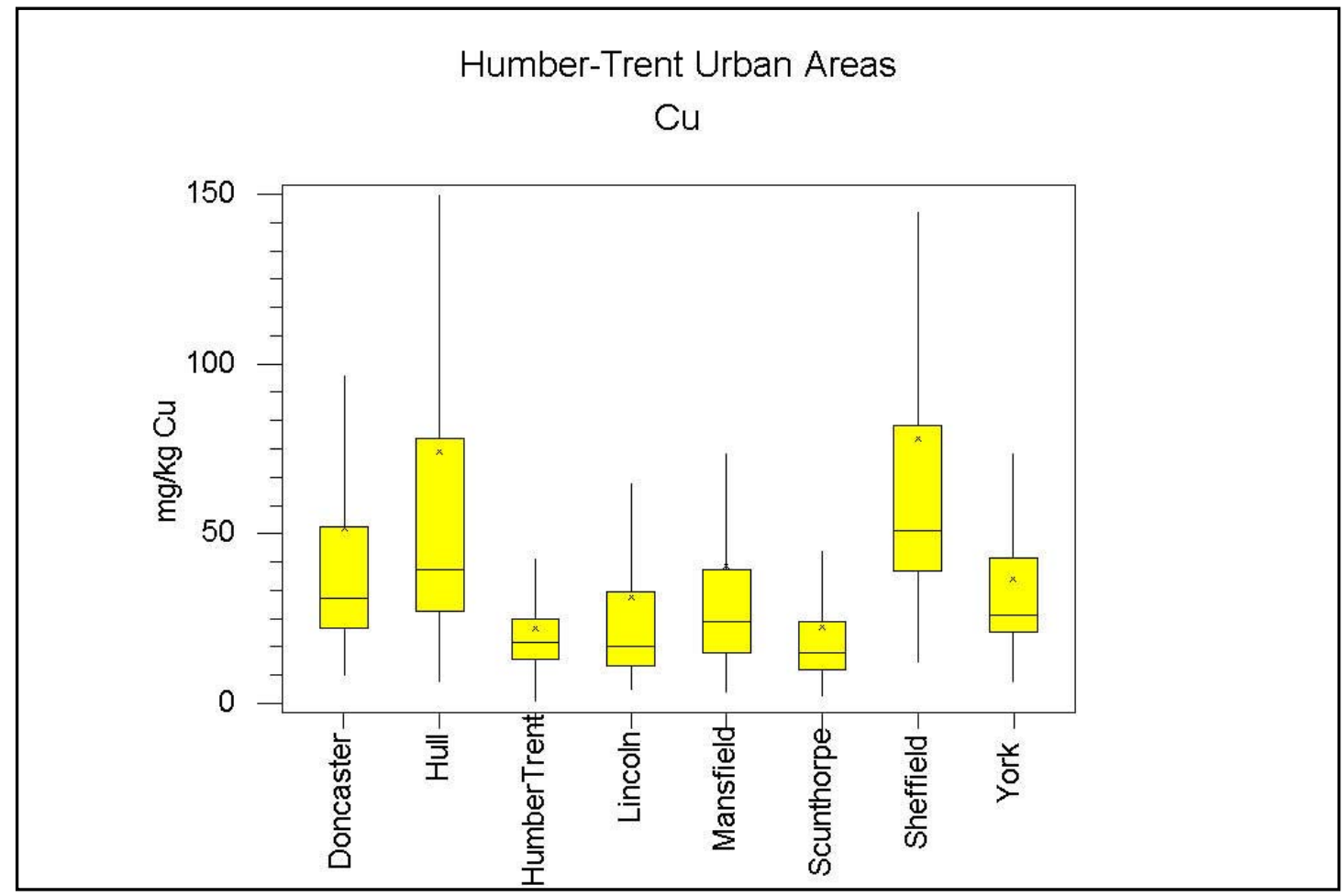

$x=$ mean value 
Figure 10 Total concentrations of selected elements in deeper $(0.50 \mathrm{~m})$ soils over different rock types in the rural and urban environment of Stoke-on-Trent

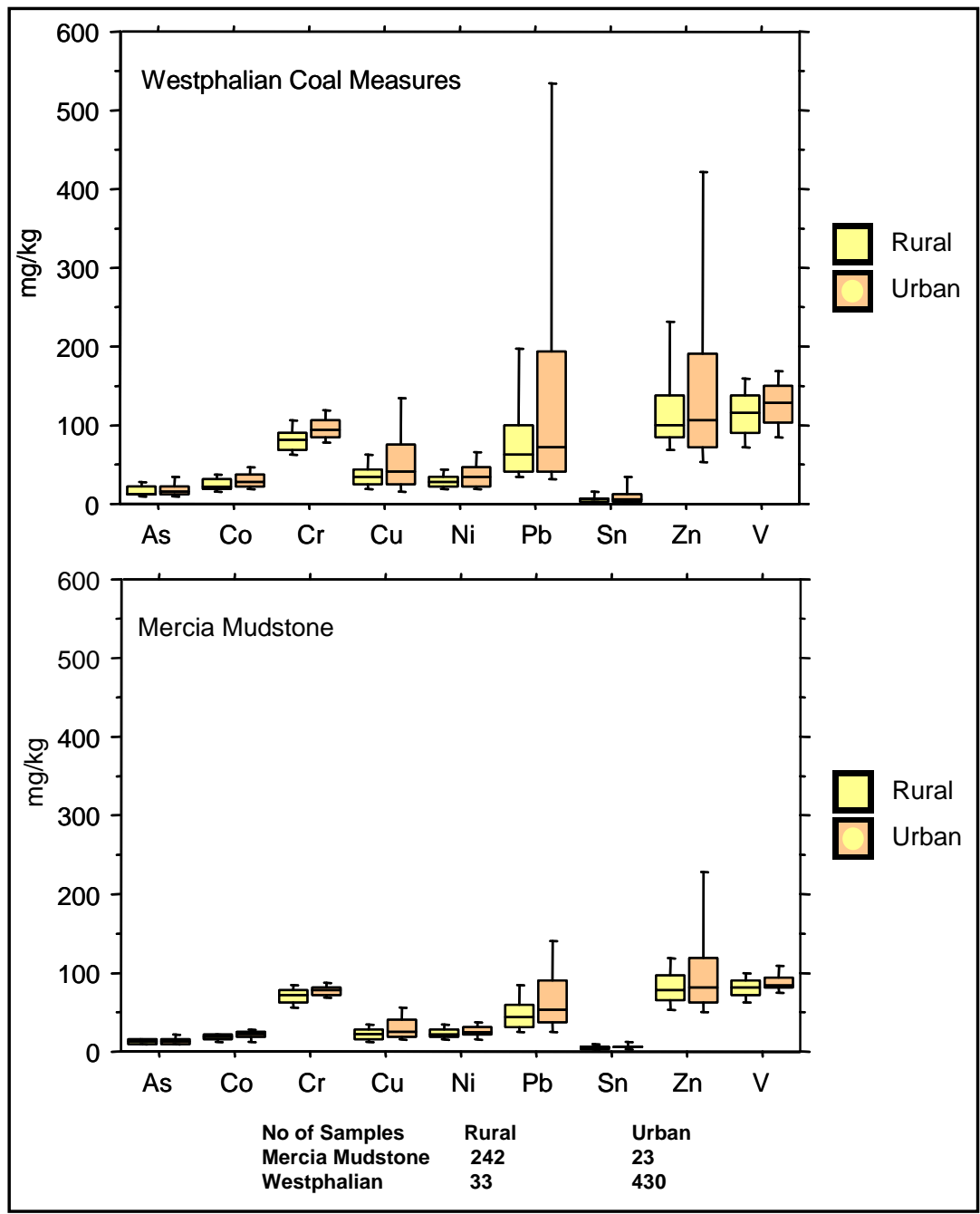


Figure 11 Bar chart showing the median of total concentrations of selected elements in surface soils $(0.20 \mathrm{~m})$ from Stoke-on-Trent, Swansea, Cardiff and Telford urban centres

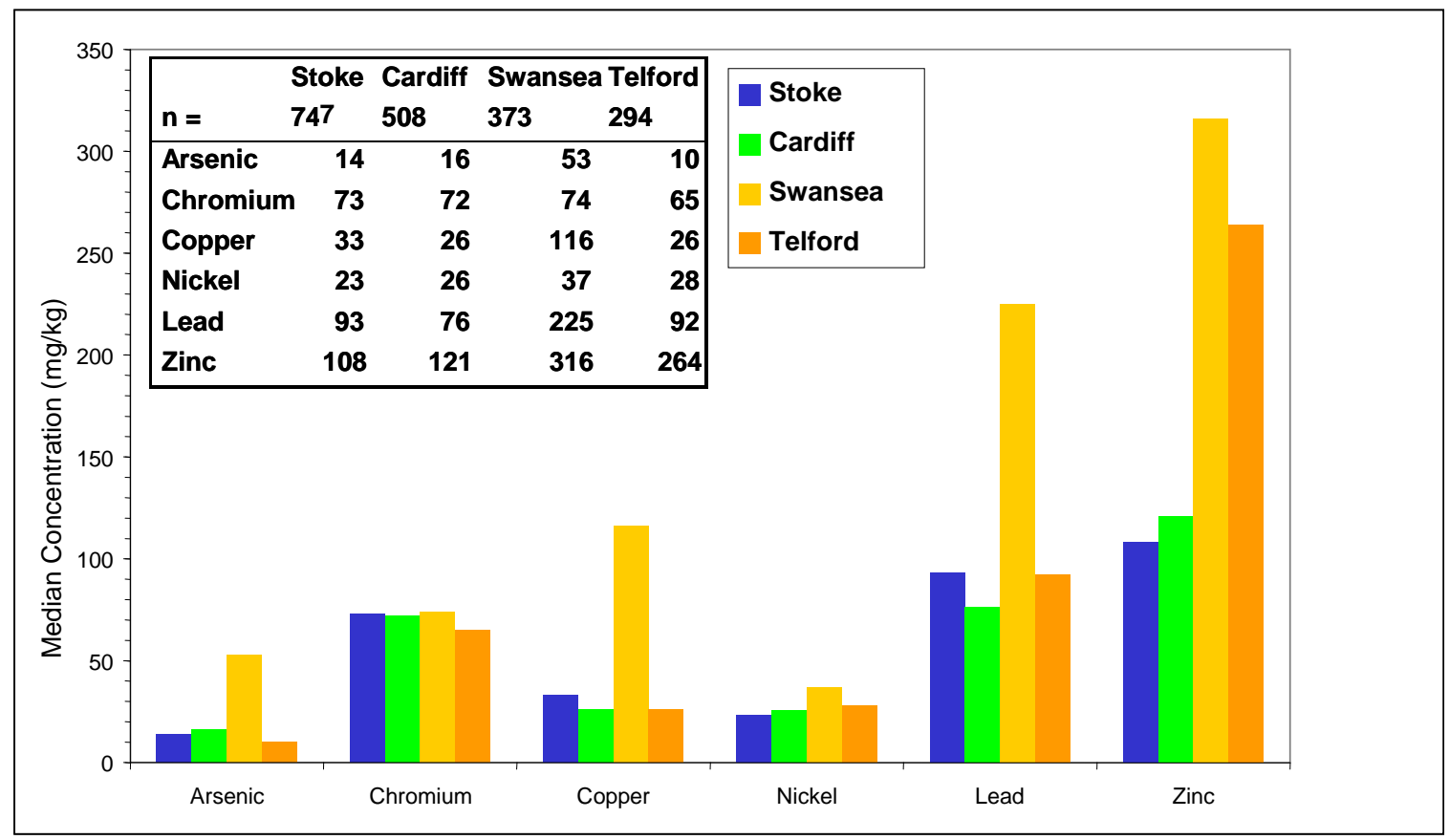


Figure 12 Total Sn concentrations in surface soils $(0.20 \mathrm{~m})$ from the Hull region

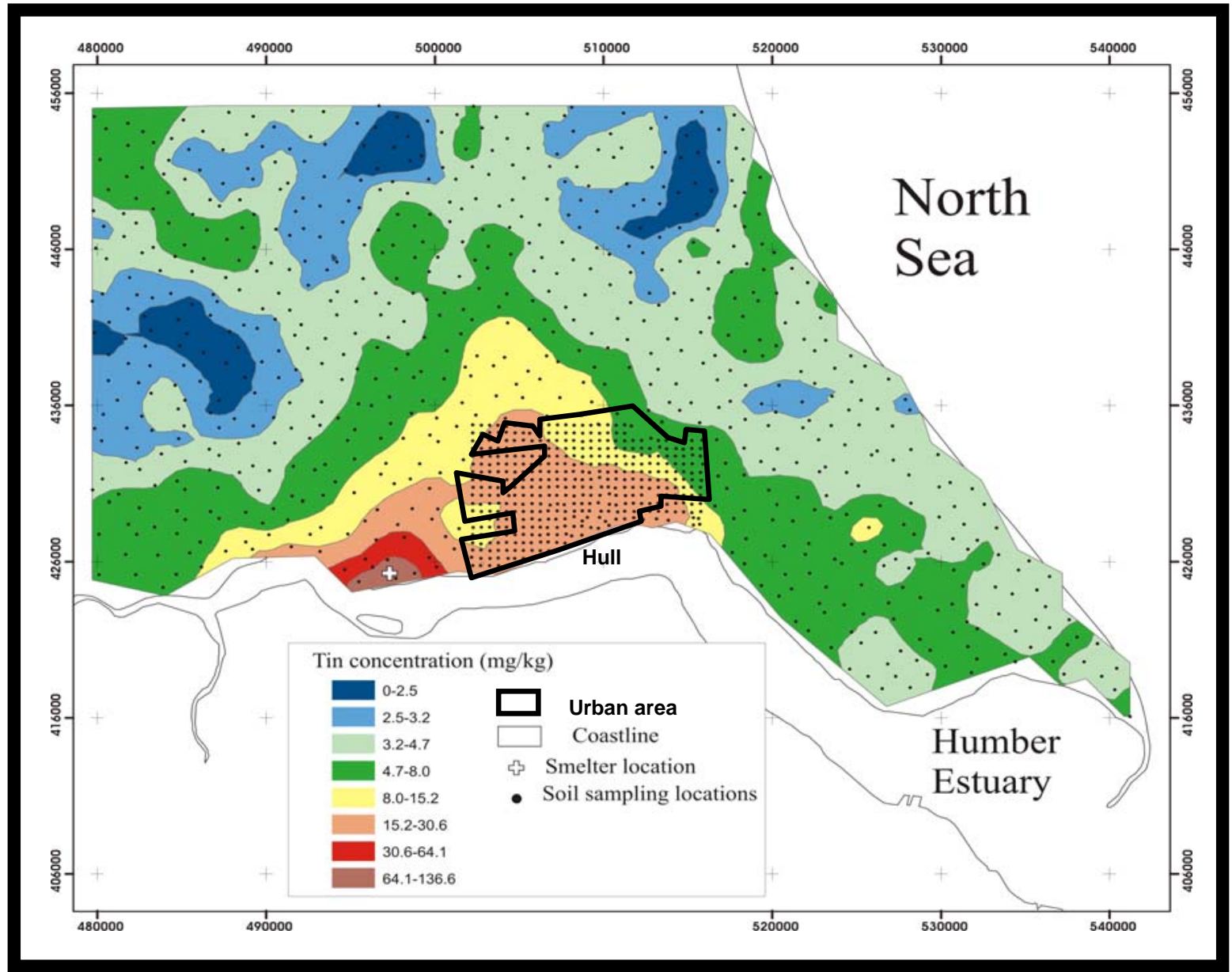


Figure 13 Box and whisker plots of the $10^{\text {th }}, 25^{\text {th }}, 50^{\text {th }}, 75^{\text {th }}$ and $90^{\text {th }}$ percentiles of total As distribution in deeper $(0.50 \mathrm{~m})$ soils from Stoke-on-Trent categorised on the basis of underlying made ground type

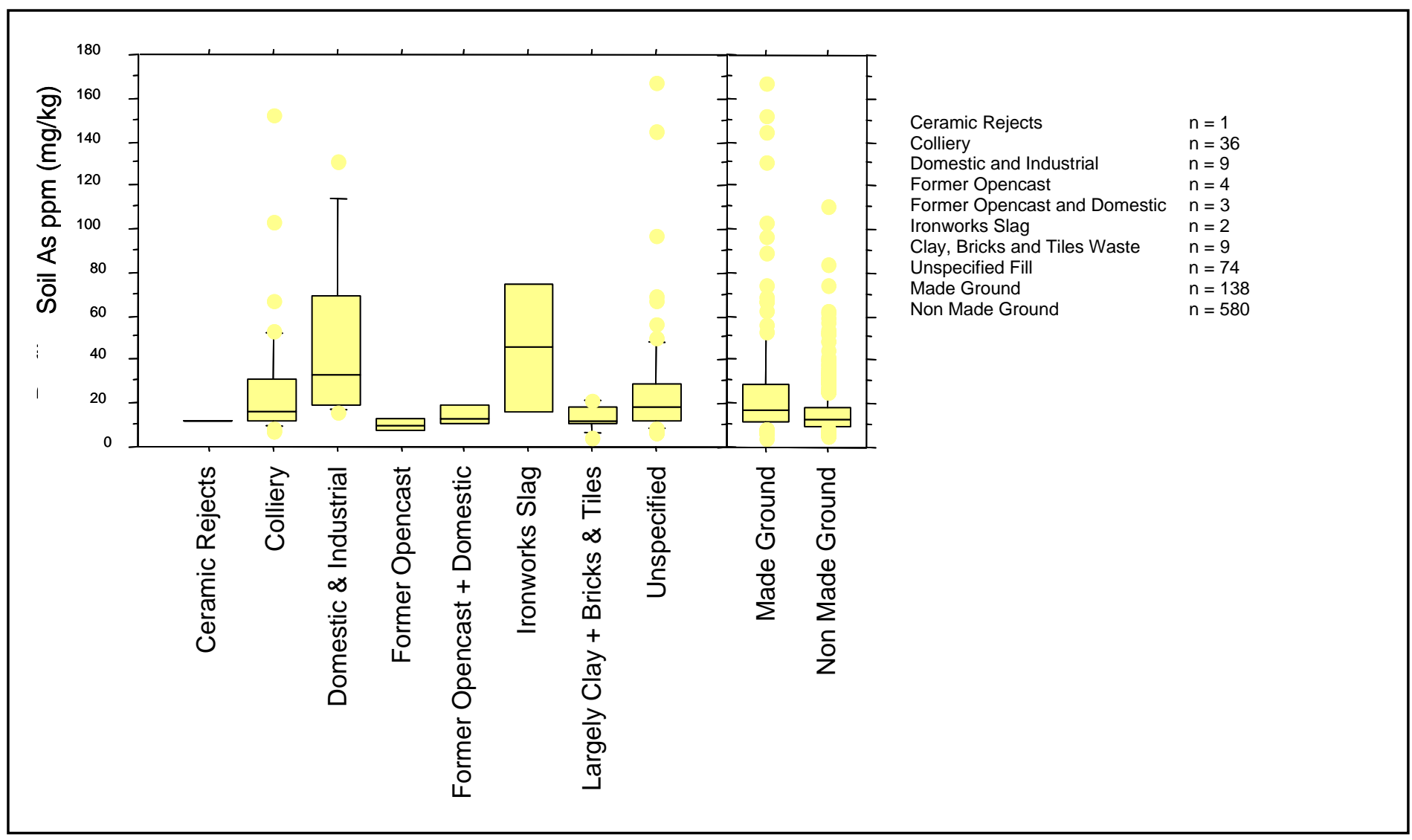


